\title{
Empowerment and life satisfaction: evidence from Bangladesh
}

Article

Accepted Version

Creative Commons: Attribution-Noncommercial-No Derivative Works 4.0

Asadullah, N., Hossain, M. and Kambhampati, U. (2019) Empowerment and life satisfaction: evidence from Bangladesh. World Development, 122. pp. 170-183. ISSN 0305-750X doi: https://doi.org/10.1016/j.worlddev.2019.05.013 Available at https://centaur.reading.ac.uk/83819/

It is advisable to refer to the publisher's version if you intend to cite from the work. See Guidance on citing.

To link to this article DOI: http://dx.doi.org/10.1016/j.worlddev.2019.05.013

Publisher: Elsevier

All outputs in CentAUR are protected by Intellectual Property Rights law, including copyright law. Copyright and IPR is retained by the creators or other copyright holders. Terms and conditions for use of this material are defined in the End User Agreement.

\section{www.reading.ac.uk/centaur}

\section{CentAUR}

Central Archive at the University of Reading

Reading's research outputs online 


\title{
Empowerment and Life Satisfaction: Evidence from Bangladesh
}

\begin{abstract}
In this paper, we examine the relationship between life satisfaction and empowerment in rural Bangladesh. We analyse this relationship across region, religion, gender and income categories using data from the BIHS 2012. This dataset has detailed socio-economic information on co-resident couples and also provides information on the empowerment of individuals within the household. We correct for endogeneity both by including a range of community and household fixed effects to capture the impact of omitted variables as well as by estimating an instrumental variable model in which the average participation rate in community activities is our identifying variable. Our results are robust and indicate a positive relationship between empowerment and life satisfaction. Analysing the sub-components of the empowerment index, we find that women draw less satisfaction from having a say in production decisions and use of borrowed money but gain more satisfaction from membership in groups. The puzzle of "contented women" (i.e. the gender gap in life satisfaction) therefore is partly explained by the fact that men and women differ in the way they draw satisfaction from different domains of empowerment.
\end{abstract}

Key words: Empowerment index; Gender inequality; Poverty; Subjective well-being. JEL classifications: I31, I10, J14 


\section{Introduction}

In this paper, we analyse the impact of gender and empowerment on life satisfaction (henceforth LS) in Bangladesh. The quality of women's life in developing countries is adversely affected by multiple forms of deprivation. Not only do they face a greater burden of financial poverty, but women also suffer from intra-household inequalities in the allocation of food and health inputs (Chen, Huq, \& D’Souza, 1981) and physical and sexual violence within marriage. Very often they lack voice and say in family matters and household spending decisions (Klugman, Hanmer, Twigg, Hasan, \&McCleary-Sills, 2014) which can adversely affect health and educational outcomes across generations (Hoddinott, \& Haddad, 1995; Quisumbing \& Maluccio, 2003; Schuler \& Rottach, 2010). What impact does this lack of voice and the poor levels of welfare have on women's subjective well-being (henceforth SWB)? Studies examining women's life satisfaction are limited and there are fewer yet in the context of developing countries. Much of the past research on the determinants of SWB in developing countries has mostly focused on economic factors despite the fact that evidence of sustained gains in SWB from higher income or wealth is debatable (Clark, Frijters, \& Shields, 2008; Easterlin, McVey, Switek, Sawangfa, \& Zweig, 2010; Senik, 2014; Easterlin, 2017).

Our analysis in this paper is based on a nationally representative survey data set -- the Bangladesh Integrated Households Survey 2012 (henceforth BIHS 2012). We particularly consider the impact that empowerment along a number of axes might have on the subjective well-being of individuals. While definitions of empowerment vary in the literature (for a review, see Pereznieto \& Taylor (2014)), we follow that of Kabeer (2001) and Schuler and Rottach (2010) who argue that empowerment is the expansion of people's ability to make strategic life choices and exercise agency in day-to-day life matters in a context where this 
ability was previously denied to them. To be specific, empowerment would then include control over a range of personal decisions, domain specific autonomy, household decision making and the ability to change one's life at both the individual and communal levels (Ibrahim \& Alkire, 2007). Kabeer (2005) further explored the concept of 'empowerment' and incorporated 'gender inequality' stating that ideological values and institutional structures prejudiced to any explicit gender constrain people's ability to make strategic life 'choices' and facilitate further inequalities. In a review of 70 evaluations of empowerment, Pereznieto and Taylor (2014) define empowerment as a process whereby women and girls experience transformation in power, agency, and in particular, economic advancement. In this context, they categorise an increase in women's power into 4 groups - power within, power to, power over and power with. In their study on empowerment from rural credit programmes, Hashemi Schuler, and Riley (1996) use 8 indicators to define empowerment including mobility, economic security, ability to make small purchases, ability to make larger purchases, involvement in major decisions, relative freedom from domination by the family, political and legal awareness, participation in public protests and political campaigning.

In this context, we consider both overall empowerment as well as the specific aspects of empowerment that are most effective. While our analysis looks into the relationship between empowerment and life satisfaction for both genders, we are particularly concerned with female empowerment. Popular perception is that Bangladeshi women are less empowered than men, making a study of the impact of female empowerment especially significant.

Our study contributes to the existing research on women's well-being in poor countries in several ways. First, we contribute to the small literature on the intrinsic importance of empowerment (e.g. Fernandez, Della Giusta, \& Kambhampati (2015)). Most existing 
studies focus on the impact of empowerment on household welfare and are less concerned with its impact on the woman's own well-being. Duflo (2012) provides a good survey of these studies. Second, we are able to make use of a multi-dimensional empowerment index in our analysis. This index, constructed following the framework of Alkire et al. (2013a, 2013b), allows us to consider the impact of empowerment along a number of axes (see also Ibrahim \& Alkire, 2007; Samman, 2007). It therefore allows us to unpack the indicators and consider which of the components of the index is most important. Third, methodologically, we address the endogeneity problem inherent in such analyses in two ways: first, by including a range of fixed effects at household and community level that allow us to correct for endogeneity arising through omitted variables. We additionally correct for reverse causality using an instrumental variable approach. Finally, Bangladesh provides an important context for research on women's well-being because it is a traditional, patriarchal society but one in which the government has made significant progress in improving women's education and empowerment (Asadullah, Savoia, \& Mahmud, 2014). Thus, it is clearly a society in which gender norms though very rigid are being pushed. Analysing the impact of empowerment on well-being in such a society is likely to be very revealing.

Our results confirm a very strong positive association between an individual's empowerment and overall life satisfaction. In addition, our analysis reveals that rural Bangladeshi women are better satisfied with life than their male counterparts who are similar in terms of empowerment, demographic, health, economic and household specific factors. Consistent with other developing country studies, the income effect we estimate is significant and stronger among the poorest but does not explain the empowerment-LS gradient. The empowerment effect is highly significant and positive for both men and women but becomes insignificant for men when treated as endogenous in the well-being function. Our 
disaggregated analysis across the domains of empowerment indicates that the economic components (including ownership and use of assets, input into production decisions and so on) are highly significant as is satisfaction with leisure.

Lastly, in the absence of an exogenously assigned intervention that empowers women in terms of access to paid work, credit and information on their legal rights, we have followed the literature that employs non-experimental methodology (e.g. Anderson \& Eswaran, 2009; Samarakoon \& Parinduri, 2015) to establish the causal effect of empowerment on LS. Key to our identification strategy is the active participation of other women in the village in community activities. The role played by social capital in empowering women has been highlighted by Stewart (2005) as well as Cheung Mok, and Cheung (2005) who test this in the context of the membership of self-help groups in China. We empirically show that localities in which female participation in community activities is high are those where women are more empowered. We hypothesize that this positive association arises either because of peer (or social interaction) effects in community participation (e.g. an individual woman is more likely to engage in community activities if others also participate) or shifting attitudes towards women (e.g. greater presence and engagement of women in the community makes it more acceptable for them to be visible outdoors and for husbands to share responsibility within the household). Having said this, while women's participation in activities within the community in which a woman lives may be a good instrument for an individual woman's empowerment, we need to be careful to exclude the individual woman herself from the instrument. This is because an individual woman's own participation in community activities is endogenous, even though the participation rate among other women in the village is beyond the influence of our individual female respondent. Therefore community-level participation rate is akin to a treatment variable, albeit a continuous one. 
The rest of the paper has been organised as follows. The next section discusses the literature and section 3 some background information on women's status in Bangladesh. The data source, sample characteristics, and estimation strategies are explained in section 4 . The main results are discussed in section 5. Finally, section 6 states concluding remarks.

\section{Literature Review}

This paper draws on two sets of literatures - the first on gender and subjective well-being and the second on female empowerment. Whether and why women are more or less satisfied with life relative to men remains debated in the literature (Boye, 2009; Della Giusta , Jewell, \& Kambhampati, 2011; Matteucci \& Lima, 2016; Asadullah, Xiao \& Yeoh, 2018; Herbst, 2011; Asadullah \&Chaudhury, 2012; Chui \& Wong, 2016). Analysing the impact of work on the life satisfaction of women, some studies find a small gap between working and nonworking women (Beja 2013; Başlevent \& Kirmanoğlu, 2017) while others (mostly in high income countries) find the opposite - women tend to be more satisfied at work or happier with life compared to men (Clark 1997; Tesch-Römer, Motel-Klingebiel, Tomasik, 2008; Graham \& Chattopadhyay, 2013; Meisenberg \& Woodley, 2015; Matteucci \& Lima, 2016). There can also be important gender differences in social preferences (Croson \& Gneezy, 2009) and material aspirations (e.g. Plagnol \& Easterlin, 2008) which can cause gender differences in the valuation of empowerment and its impact on life satisfaction. The impact of gender on SWB measures such as happiness and life satisfaction is not surprisingly, contextspecific. In Bangladesh, women are disadvantaged relative to men with respect to inherited assets. They are also deprived of important capabilities such as health and education (Sraboni, Malapit, Quisumbing, \& Ahmed, 2014) and the absence of these substantive 
freedoms leaves women disempowered to live the life they desire and can undermine their welfare (Graham \& Nikolova, 2015). In the Bangladesh context, therefore, Devine, Camfield, and Gough (2008) emphasize the critical importance of the ability to manage households, raise children well, and support aging parents in the descriptions many Bangladeshi women offer of their personal wellbeing. This is consistent with existing evidence of the high value Bangladeshi women place on caring for their families (Camfield, Choudhury, \& Devine 2009). Yet they also note the importance of financial independence and mobility in women's statements regarding their quality of life (Devine et al. 2008).

Empowerment in the form of participation in household decision making is an important capability and matters for life satisfaction (Sen, 2008; Veenhoven, 2010) because it both decreases the constraints that women face in resource allocation and decision making and also increases women's responsibilities both within and outside the home. The net impact of these two processes is uncertain. Women's empowerment can be seen as a process that increases autonomy and control over personal decisions, say in household decision-making, and expands the capability to change aspects in her life (Ibrahim \& Alkire, 2007).

It is often argued that women's rights and family responsibilities have not changed despite improvements in labour market outcomes and this has led to women bearing a double burden that cuts into their leisure leading to SWB loss (Stevenson \& Wolfers, 2009) ${ }^{1}$. In developing countries, this 'double burden' (of housework and external work) seems to go hand in hand with a lack of empowerment in many aspects of women's lives. Mahmud Shah, and Becker (2012) also caution that empowerment brings with it both rights and the burden of

${ }^{1}$ For evidence on leisure and the perceived quality of life, see Lloyd \& Auld (2002), Iwasaki (2007) and BrajšaŽganec, Merkaš, \& Šverko (2011). 
responsibilities (see also Fernandez et al (2015)). Economic participation can raise women's relative bargaining power but it also implies additional responsibility which may not necessarily be welfare enhancing. The greater mobility and visibility of working women, while empowering, can also lead to increased exposure to violence and decreasing support from men in taking critical decisions (Heath 2014) ${ }^{2}$. Similarly, some evidence shows lower subjective wellbeing among participant rural women in NGO interventions because by promoting women's involvement in household income generation, these programs also increase emotional stress among them (Ahmed, Chowdhury, \& Bhuiya, 2001). Therefore, Basu and Koolwal (2005) argue, the real measure of autonomy is not whether women have the freedom to do certain things but what would happen if they chose to ignore these freedoms. For both (women and men), true freedom requires some self-indulgence and the freedom to do unproductive things (listen to the radio, visit friends and so on). Hence, whether women's empowerment leads to higher SWB in all settings is an important research question.

We are only aware of one study, Fernandez et al. (2015), that has examined women's SWB as a function of agency. The authors, analysing this issue in the context of Indonesia, concluded that women (and men) are happier when most decisions are jointly made rather than solely. They find that while men are happier when they can take financial decisions jointly with their spouse and can control child-related decisions, a woman's wellbeing is not related either to the proportion of household decisions made by her spouse, or to child-related expenditure decisions. Women seemed to be less happy if they alone are to take decisions on

${ }^{2}$ Heath (2014) finds that working for pay is positively correlated with intimate partner violence in rural Bangladesh among women who married at a young age or have low levels of education. 
issues such as savings leading the authors to conclude that collaborative approaches or relinquishing control (in some cases) were associated with higher well-being for women.

Before we go any further, it would be useful to consider the South Asian context generally and that in Bangladesh in particular in the next section.

\section{Study Background}

Women in South Asia face greater social barriers and more restrictive gender norms and social customs than elsewhere. Patriarchal norms and values have long been institutionalised in rural Bangladesh. Within the household and beyond, men exercise control over women's labour, their sexuality, their choice of spouse, their access to labour and other markets, and their income and assets through local decision-making and legal bodies. State legislations and institutions underpin this gender subordination and dependence, in spite of constitutional affirmations of gender equality (Alim, 2009). According to one household survey in rural Bangladesh, 78 percent of women said they had at some point been forced to cede money to their husbands, and 56 percent said that their husbands had forced them not to work outside the home (Pitt, Khandker, \& Cartwright, 2006).

In recent decades, however, the lives of Bangladeshi women have been transformed in a number of ways. First, women have been rapidly drawn into the labour market through employment in rural road infrastructure projects (Khandker, Bakht \& Koolwal at al. 2009) and expansion of the readymade garment sector (Feldman, 2009). Regular paid employment of this kind contributes to women's voice and agency and by feminizing the urban public space has possibly created new social norms that are supportive of women's physical mobility and access to public institutions (Hossain, 2011). Unsurprisingly, it has also 
improved women's living (Hewett, Amin \& Sen, 2001). A second major institutional development is the rise of female-targeted microcredit NGOs which has led to a number of positive changes in women's perceptions of themselves, and their role in household decision making. It has been associated with reduced violence against women, an increase in women's assets (Kabeer, 2005), to greater mobility and improved bargaining power (Schuler et al. 1996) for women. Finally, a third development has been an improvement in girls' education in Bangladesh, with the enrolment of girls in primary education now superseding that of boys in the country and also that of girls in most other countries in South Asia (Asadullah et al., $2014)^{3}$. Increased exposure to schooling can be expected to positively impact agency in the younger cohort of married women by giving them a voice and say.

Despite the above progress with respect to women's empowerment, traditional gender norms which constrain women's life choices in rural areas remain. The majority of Bangladeshi women are married off at a young age, soon after puberty, and are often mothers before their $18^{\text {th }}$ birthday. The custom of early marriage itself serves as a pathway for the transmission of patriarchal attitudes and norms shaping gender roles and rights within the household (Asadullah \& Wahhaj, Forthcoming). While working women in urban Bangladesh have successfully negotiated the terms of the purdah ${ }^{4}$ norm by redefining it as a state of mind instead of its traditional form of physical absence from the public space, paid work participation in rural areas is still stigmatized and norms of purdah still impinge on women's political participation in rural areas. Moreover, reproductive responsibilities and the genderspecific burden of unpaid household and care work limits the time women can devote to paid

\footnotetext{
3 This is arguably due to the government's Female Secondary School Assistance Programme (FSSAP) for secondary school going girls introduced in the early 1990s, which provided free studentships, distributed free books, provided registration fees, attempted to secure a girl-friendly environment in schools, amongst other things. ${ }^{4}$ In rural Bangladesh context, the term Purdah usually refers to the Muslim custom of veiling though it also represents society-wide rules and restrictions on outside movement and interactions of women with non-kin men.
} 
work (Mahmud, 2003). Most economic opportunities for women in rural areas are home based or agricultural, with women today accounting for a large proportion of the agricultural workforce. However, the overall national female labour force participation rate still remains low (Asadullah and Wahhaj, 2016).

Given these contradictory trends in gender norms in Bangladesh, an empirical analysis of their impact on women's life satisfaction, particularly for those involved in agriculture, is overdue. This is what we turn to next.

\section{Data, Measurements, and Survey Description}

Our data have been drawn from the Bangladesh Integrated Households Survey 2012, designed and implemented by the International Food Policy Research Institute (IFPRI) (Sraboni, Quisumbing, \& Ahmed, 2014). The BIHS sample is statistically representative at the following levels: (1) nationally representative of rural Bangladesh; (2) representative of rural areas of each of the seven administrative divisions of the country. The sample design followed a stratified sampling in two stages - selection of PSUs and selection of households within each PSU—using the sampling frame developed from the community series of the 2001 and 2011 population censuses of Bangladesh. In the first stage of sampling, the total BIHS sample of 325 PSUs were allocated among the 8 strata with probability proportional to size. In the second stage, 20 households were randomly selected from each PSU or villages. A complete census in each of the 325 selected villages was conducted to create a village-specific census list which was then used to select the sample households.

The survey collected information from both primary male and primary female respondents within a household in order to facilitate the construction of the Women's Empowerment in 
Agriculture Index (WEAI). This was based on a specially designed module following Alkire et al. (2013b). While the total BIHS sample comprises 6,500 households in 325 villages, 4,610 of these are agricultural households. Since we want to study the empowerment-well-being gradient by gender in a household context, we focused on 3860 households with cohabiting couples.

The BIHS data has two significant advantages for our analysis. First, it has collected information not just on life satisfaction but also on empowerment. The life satisfaction scores in the BIHS are based on the question "how would you rate your satisfaction with your life overall on a scale of 1 to 10 , where 1 means you are not satisfied and 10 means you are very satisfied?".

The empowerment variable, in its turn, is a multi-dimensional index which captures empowerment in agricultural decisions as well as community life and leisure (Sraboni et al, 2014). This variable - the WEAI - is composed of two sub-indexes: the five domains of the empowerment index, and the gender parity index (Alkire et al., 2013a; USAID, IFPRI, \& OPHI, 2014). Given our focus on individual level analysis, we concentrate on the first component of the index- the five domain empowerment index - which includes decisions about agricultural production ("Production decision making"), access to and decision making power over productive resources ("Access to productive resources"), control over use of income, leadership in the community and time allocation. Adequacy over these five domains is measured using 10 indicators. Each indicator is given a value of 1 if the respondent has exceeded a certain threshold; otherwise a value of 0 has been assigned (see Alkire et al., (2013b) for further details). The 10 indicators with their corresponding weights have been presented in Table 1, with the weighted sum of these indicators yielding the five domain 
empowerment index. A person is defined as "empowered" if her or his score is 80 percent or higher i.e. they are empowered in at least four domains (Alkire et al., 2013a; Sraboni et al., 2014).

Table 1 indicates that among the 10 sub-indicators, the largest proportion of women's adequacy relates to control over the use of income and the smallest is in relation to the workload (with only $18 \%$ of women having autonomy in this indicator). For men, the highest proportion of adequacy is in the ownership of assets (97\%) and transacting in these assets (98\%). The lowest proportion is in group membership.

[Tables 1-2 about here]

\section{Empirical strategy}

As already indicated, our main objective is to examine the relationship between empowerment and life satisfaction. Since we are particularly concerned about the empowerment of women within households, we focus on the sample of married individuals. For this purpose, we estimate the following model:

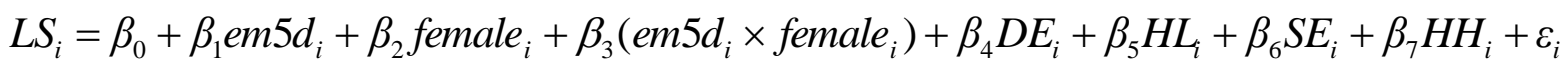

where $\mathrm{LS}_{\mathrm{i}}$ stands for the self-reported life satisfaction score of the i-th respondent and $\varepsilon_{\mathrm{i}}$ stands for error term. Our main parameters of interest are $\beta_{1}$ and $\beta_{2}$, the coefficients on the five domain empowerment index and on the female dummy, respectively. Our model controls for common demographic (DE), health (HL), socioeconomic (SE), and household (HH) specific factors which have been included in previous studies of life satisfaction in Bangladesh and other Asian countries (Asadullah \& Chaudhury, 2012). 
The main demographic factors that we control for are age, age squared, marital status, and religion. We also control for health by including height, incidence of illness, and presence of physical disability. Socioeconomic controls include educational attainment of the individual and their employment status; while household level factors include per capita monthly household expenditures, whether the household head is female, as well as the occurrence of any positive economic event and exposure to negative shocks ${ }^{5}$. We also control for women's engagement in formal income earning activities because of the evidence on the positive link between women's empowerment and participation in such activities (e.g. Majlesi, 2016) as well as employment being a key determinant of SWB.

In order to control for the possibility that the household income effect merely captures the effect of meeting the basic needs of life, we additionally control for the condition of dwelling and electricity connection in the house. Table 2 provides summary statistics of these control variables. We see, for instance, that women in our samples are on average younger (at 37 years) than men (46 years) and while they are also less educated, the difference is not very large (2.975 years for women as opposed to 3.026 for men). Fewer women than men in our sample worked for pay. There were more households which faced significant negative shocks than those which faced significant positive events.

Finally, we also control for household composition, in particular, the number of child (0-14 year) dependents, number of female dependants ( $>60$ years) and number of male dependants

\footnotetext{
${ }^{5}$ In our data, $56 \%$ households faced negative shocks in the past 5 years of the survey while 6 percent experienced some kind of positive economic event in the past 5 years of the survey.
} 
(>60 years $)^{6}$. For the female subsample, we additionally control for whether the mother-inlaw lives in the household (11 percent of women live with mothers-in-law in our sample). This is because a woman's well-being might be affected by living in an extended family with her mother-in-law ${ }^{7}$.

Since the BIHS life satisfaction variable is an ordered variable, we use the ordered probit methodology to estimate the life satisfaction function. We also report OLS estimates for comparison purposes. In fact, a number of studies (e.g. Bojanowska \& Zalewska, 2016; Knight, Song, \& Gunatilaka, 2009) have treated the well-being score as a continuous variable and others have shown that results do not depend on whether satisfaction is considered as a cardinal or an ordinal variable (Della Giusta et al., 2011; Ferrer-i-Carbonell \& Frijters, 2004). Not surprisingly, we see that the 5 domain empowerment index is higher for men (at 0.693 ) than for women (0.598). However, there is almost no difference in raw life satisfaction scores for men (7.088) and women (7.066).

\section{Endogeneity and Instrumentation}

One of the problems with modelling life satisfaction is the endogeneity inherent in many of these models, which is likely to bias our estimates. Such endogeneity might occur for two reasons - variables omitted from the model or the reverse causality problem (Fernandez et al., 2015). Wellbeing functions are often seen as having some omitted variables at community, household or personal levels. In particular, it is possible that community level gender norms

\footnotetext{
${ }^{6}$ Household composition, particularly presence of dependent children, can matter for life satisfaction For example, Della Giusta et al., (2011) showed that life satisfaction of those women who are responsible for caring of dependents has a statistically significant negative relationship with time spent on caring. For other related studies, see Deaton \& Stone (2014), Conzo, Fuochi, \& Mencarini (2017), Myrskylä \& Margolis (2014) and PollmannSchult (2014).

${ }^{7}$ Available evidence for rural Bangladesh confirms that women who do not live in the homes of their in-laws, and/or who reside in relatively lenient households are more likely than others to have greater authority and mobility (Balk 1997; Schuler \& Rottach, 2010).
} 
might influence women's wellbeing. These could include certain aspects of patriarchy that might reveal themselves in purdah, marriage practices or even practices like female genital mutilation in some parts of the world (though not practised in Bangladesh). Similarly, regional variations in economic activity or coverage by the microcredit or textile sectors could also influence both empowerment and life satisfaction of women. In addition, there could be household level variation in norms that are not captured in our empowerment indices. Correcting for omitted variables of this kind is not always easy because such factors are not easy to measure. In our analysis in this paper, therefore, we correct for them by including household and regional fixed effects which will capture the impact of household and regional norms that are not explicitly controlled for in our models. Thus, we estimate a community fixed effects model to pick up omitted locality specific gender and cultural norms (e.g. the custom of purdah governing the outside engagement of women and hence their threat points in intra-household bargaining) as well as a household fixed effects model which will control for time invariant household specific factors.

A second cause of endogeneity is likely to be reverse causality from life satisfaction to empowerment. It is possible, for instance, that happier women are more likely to proactively take on decision-making within the family and on farms. They are also more likely to acquire greater capabilities through such engagement. To correct for this possibility, we estimate an IV model (equations 2 and 3) wherein we explicitly model empowerment and identify this equation by including participation in community activities as our instrumental variable.

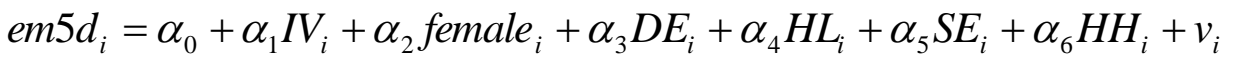

$$
\begin{aligned}
& L S_{i}=\gamma_{0}+\gamma_{1} e \hat{m} 5 d_{i}+\gamma_{2} \text { female }_{i}+\gamma_{3} D E_{i}+\gamma_{4} H L_{i}+\gamma_{5} S E_{i}+\gamma_{6} H H_{i}+u_{i}
\end{aligned}
$$


It is worth noting that we use the "average number of community activities participated by others in the community" ${ }^{\prime}$ as our instrumental variable because an individual's own participation is likely to be endogenous. ${ }^{9}$ Therefore, in constructing the excluded variable, we drop data on the index respondent ${ }^{10}$. Our summary statistics (Table 2) indicate, not surprisingly, that women participate in fewer community activities (0.816) than men (1.578). We then include this IV in our second stage estimation.

\section{Results and discussions}

The ordered probit estimates of the determinants of life satisfaction are presented in Table 3 . In addition to variables described in equation (1), all regressions control for division (largest administrative unit in Bangladesh) dummies. Before we discuss these results, we will summarise the impact of our controls on life satisfaction.

Our results (Table 3) indicate that education has a positive and significant impact on the life satisfaction of both men and women. This is an important result and one that varies from others in developed country contexts (e.g. Clark \& Oswald, 1996) which indicate that education often leads to lower life satisfaction ${ }^{11}$, possibly because it increases expectations.

\footnotetext{
${ }^{8}$ In the BIHS 2012 questionnaire, seven questions are included relating to community activities. These are: "In the last 12 months, have you (1) contributed money or time to building small wells or maintenance of irrigation facilities in your community? (2) contributed money or time to building or maintaining roads in your community? (3) contributed money or time to town development projects or public works projects in your community? (4) contributed money or time to building or maintaining your local mosque/church/temple? (5) in the last year, did you give money to any other family because someone in their family was sick? (6) in the last year, did you help another family out with agricultural labour? (7) in the last year, did you help another family out when they needed help with child care?" Thus the aggregate response range for each individual in terms of the number of community activities participated by the individual is between 0 and 7 .

${ }^{9}$ On the link between volunteering/social activities and personal well-being, see Borgonovi (2008), Casiday Kinsman, Fisher, \& Bambra (2008) and Thoits \& Hewitt (2001).

${ }^{10}$ This instrument is therefore an index measured at community level that captures (community) average participation rate in 7 activities.

${ }^{11}$ For recent developed country studies reporting positive education effect, see Cuñado \& Gracia (2012).
} 
The most researched correlate of SWB in the literature -household income -- also has a positive and significant impact on life satisfaction for both men and women in our data.

Turning to our main variables of interest - the empowerment index and the female dummy we find that the coefficients of both variables (Table 3) are statistically significant and positive. This indicates that women have significantly higher life satisfaction in Bangladesh than men and so do empowered individuals. The significant gender difference in life satisfaction in rural Bangladesh is in line with the international literature on contented women (Clark, 1997). It is interesting to note that this is true despite the fact that the raw data does not reveal a large difference in life satisfaction scores of women relative to men (see Table 2). However, once we control for the very different conditions in relation to education, income, empowerment, age etc. between the genders, women are more satisfied than men (see Table 3).

As mentioned already, we estimate our models using household (Column 3) and community (Column 4) fixed effects in order to capture the effect of omitted community and household specific variables. The fixed effects approach relies on a linear (i.e. OLS) regression model. ${ }^{12}$ However, our key parameters of interest, the coefficients on female dummy and the empowerment variable remain unchanged in terms of sign and significance though the coefficient drops in magnitude when we include household fixed effects.

The question following on from our results above is whether empowerment itself has a differential impact on life satisfaction for men and women. This is revealed in the coefficient

\footnotetext{
${ }^{12}$ We checked the robustness of our findings by treating life satisfaction as ordinal instead of cardinal (i.e. model 2 of Table 3). The estimated coefficients are similar across models 1 and 2 confirming no qualitative differences to the significance, and sign, of the coefficients whether one treats life satisfaction responses as cardinal or ordinal in the life satisfaction equation. This is consistent with the findings of Ferrer-i-Carbonell and Frijters (2004).
} 
of the interaction term between the empowerment index and the female dummy in Table 3 as well as our separate estimates for the male and female sub-samples (Table 4) and men (Table 5). Before we do so, however, we will consider the results for our IV models which correct for the endogeneity of the empowerment index. These results are presented in columns 5 and 6 of Table 3. Our first stage results indicate that our instrument, gender-specific average participation in community activities, is significant and robust. Our Stage 2 results (for the OLS model) indicate that empowerment remains strongly positive and significant in influencing life satisfaction in Bangladesh (Table 3, column 6). We note, however, that the IV coefficient is larger than either our OLS or OP estimates. Thus, empowerment and the ability to make decisions in relation to a range of issues in life helps to increase an individual's satisfaction with life in Bangladesh, contrary to the findings of Fernandez et al. (2015) for Indonesia. Before we consider which aspects of empowerment are especially significant in influencing life satisfaction, we will consider whether empowerment has a differential impact on life satisfaction amongst men and women.

\section{Gender Disaggregated Results}

The coefficient of the interaction term between empowerment and female in Table 3 is insignificant in all the models leading us to conclude that, while empowerment itself is highly significant in influencing life satisfaction, female empowerment is not more significant than male empowerment in this context. Our sub-sample results (Tables 4 and 5) indicate that, in both the OLS and the OP estimates, the empowerment index has a positive and significant impact on life satisfaction for both women and men (Tables 4 and 5 respectively). In the OLS models, we can also see that the coefficient of empowerment is lower for women (2.79 and 1.98) than for men (3.24 and 2.84). Turning to the IV estimates, we find that participation in 
community activities (our instrument) is positive and significant for both male (0.04) and female (0.07). In both samples, the F-statistic on excluded instrument is very large suggesting that our results are robust to the problem of weak instruments. However, once instrumented, we see that empowerment continues to have a positive and significant impact on life satisfaction for women but this is not so for men. Thus, once endogeneity is taken into account, we see that empowerment affects life satisfaction only for women. This might relate to the fact that empowerment is more the norm for men in Bangladesh than for women.

Among other notable findings, our results indicate that while a positive shock increases life satisfaction for both men and women, a negative shock seems to affect men's life satisfaction negatively but has no impact on women's life satisfaction i.e. women are better able to cope with negative shocks than men. The quality of living conditions (state of house, access to electricity) has the expected effects for both men and women.

[Tables 3-5 about here]

\section{Testing Robustness of our Instruments}

In a study on the determinants of household food security using the same data set, Sraboni et al. (2014) also addressed the endogeneity of women's empowerment using an IV framework. Their instruments include (1) the difference in age between primary male and female decision makers, (2) number of types of informal credit sources in village, and (3) participation in any community activities. Re-estimating our model with these instruments (see Appendix Table A), we confirm our findings in Tables 3-5 that empowerment has a positive and highly significant impact on women's life satisfaction but not on men. 
However, the instruments used by Sraboni et al. (2014) do not pass the validity test in our female subsample. For this reason, our preferred set of IV estimates in this paper correspond to those presented in Table 3-5.

We will now turn to two extensions of our analysis so far. First, we analyse this relationship in a set of sub-samples to see if the result is robust across sub-samples. Second, we disaggregate the sub-components of the empowerment index to see if a particular component has a larger or more significant impact than others.

\section{Impact of Empowerment across Sub-Samples}

We consider the empowerment - life satisfaction relationship across three further subsamples - economic (richest and poorest quartiles); religious (Muslim vs non-Muslim) and regional (integrated vs non-integrated regions ${ }^{13}$ ). Our results (Table 6) indicate that women have a higher conditional life satisfaction in the poorest quartile, amongst Muslims and in the integrated region. Thus, women in the poorest quartile are more satisfied than their male counterparts in comparison to richest women and their male counterparts. It might help to understand these results if we think of empowerment as being affected by external constraints (income in this case) and internal constraints (i.e. internal to the household). The level of external empowerment is likely to be higher for prosperous households and internal (i.e. within household) empowerment is likely to be higher for men. In this context, we might expect rich men to be the most empowered in rural Bangladesh (since they are externally empowered by prosperity and also empowered within their households). We might also expect poor women to be least empowered since they face a double disempowerment - that

\footnotetext{
13 By integrated regions, we refer to Dhaka, Chittagong and Sylhet divisions that are geographically wellconnected with each other and include all major growth centres in the country. On the other hand, non-integrated divisions (i.e. Ranpur, Rajshahi, Khulna and Jessore divisions) are separated from rest of the country by major rivers which considerably increase transport cost and movement of goods and services.
} 
from poverty and also from being a woman. Men in poor households are disempowered externally through poverty but are not disempowered within their households.

Finally, women in integrated regions are more satisfied than men in these regions though there is no significant differential in LS in the non-integrated regions. Integrated regions benefit from better communication infrastructure, lower migration cost, and greater access to market work (Shilpi, 2011) which might help to improve women's mobility and opportunities for outside engagements which in turn might help to make their life satisfaction differential relative to men larger than in non-integrated districts.

[Tables 6-7 about here]

Turning to the impact of empowerment on life satisfaction in these sub-samples, we find an unequal impact of empowerment in the poorest (1.54) and richest quartiles (1.05). In other words, empowerment has a differential impact on poorer households. Again, this is not surprising because empowerment makes up for some of the constraints placed by poverty on these households. Empowerment also has a larger impact amongst non-Muslims than Muslims and it has the largest regional impact in integrated eastern regions. Following on from this, it has a larger impact on non-integrated regions in the North than in the South.

Overall, our results confirm that though the magnitude of the impact varies across subsamples, empowerment has a positive and significant impact on life satisfaction whichever way we divide the sample.

\section{Component Indicators of Empowerment}


Turning to the 10 sub-components of the empowerment index, we re-estimate our model with a single component at a time rather than with the index overall (see Table 7). This helps us to consider whether certain aspects of empowerment are more important than others in influencing life satisfaction. In these estimations, we include a female dummy as well as female*empowerment indicator variable to capture the differential impact of the empowerment indicator on women. To understand these estimates, the coefficient of the indicator variables (i1-i10) is the effect of the empowerment indicator in the whole sample while the female indicator provides a differential impact for women. Thus, to measure the net impact of an individual empowerment indicator on women, we add the coefficient on the i-th empowerment indicator (where $i=1,2, \ldots, 10$ ) and the coefficient on the interaction term of the (i-th empowerment indicator)*(coefficient on the female dummy).

Our results indicate that the sub-components for which the level empowerment term is significant in influencing life satisfaction are i1, i2, i3, i4, i6, i7 and i10. In other words, having an input into production decisions (i1) and access to and use of borrowed money (i4) help boost life satisfaction. Similarly, having an impact on how household income is spent (i6) and on the use of assets (i4) are also very significant. These together capture economic empowerment. In addition to these 'economic empowerment' indicators, the only two other sub-components for which the empowerment variable is significant are group membership (i7) and satisfaction with leisure (i10).

The effect of these indicators is significantly different for women in two cases - i1 and i5. Having an input into production decisions has a larger impact on men's life satisfaction (0.21) than on women $(-0.18)$ giving a very small net impact of this indicator for women (0.03). Second, while borrowing does not affect the life satisfaction of men, it decreases 
women's life satisfaction considerably. This is a surprising result and may link back to the 'double burden' that many women suffer from in the context of microfinance loans in Bangladesh, for example. In particular, many microcredit loans are given to women who bear the responsibility for repaying them. This might increase the stress related to such loans (Schuler et al., 1996) which men are less likely to feel. Analysing the impact of these subcomponents, we conclude that certain types of empowerment have a larger impact on life satisfaction than other types and also these sub-components have different impacts on men and women.

\section{Conclusion}

In the South Asian context, female autonomy and/or education have been associated with increased household welfare in the form of decreases in fertility as well as improvements in health and education within the household ${ }^{14}$. In this paper, we add to the literature by asking a slightly different question: does empowerment have an intrinsic effect on an individual's life satisfaction? These are the questions we are concerned with in this paper. It is in this context that we have studied whether there is a difference in gender empowerment on life satisfaction in Bangladesh using an innovative multidimensional index of empowerment which is based on survey data of agricultural households with information on co-residing husbands and wives. We estimate a range of models to correct for potential endogeneity arising from regional and household gender norms as well as reverse causality between empowerment and well-being.

Our results indicate that the level of empowerment is significantly and positively associated with life satisfaction regardless of household income, gender, religion, and geographic

\footnotetext{
${ }^{14}$ See for instance e.g. Abadian (1996); Amin, Ahmed, Chowdhury, \& Ahmed (1994); Balk (1997); Schuler \& Hashemi (1994); Adnan (1993); Seymour (2017); Murthi, Guio \& Dreze (1995).
} 
location. Our results also clearly indicate that empowerment remains a significant factor in influencing life satisfaction across regions, religion or income groups. When we consider the specific sub-components of the empowerment index, we find that it is participation in production decisions, access to productive resources, and control over use of income which are significant in influencing life satisfaction so that women's empowerment with regard to these indicators explains gender differences in life satisfaction.

The puzzle of "contented women" (i.e. the gender gap in LS) therefore is partly explained by the fact that men and women differ in the way they draw satisfaction from different domains of empowerment. The lower level of life satisfaction owing to borrowing among women, but not men, is consistent with the notion that economically active women face the 'double burden' of providing care and fulfilling household responsibilities. It might also relate to the increased responsibilities women have for paying back these loans. Therefore, while economically active women draw satisfaction from economic empowerment, this can involve an important trade-off. Various patriarchal norms govern women's lives in rural Bangladesh irrespective of their economic engagements in a way that do not constrain and disempower men. This is possibly another explanation for why we do not find a causal effect of the empowerment variable on the life satisfaction of men in our study.

Before we conclude, it is worth reiterating that some of the limitations of our analysis. Despite relying on a rich data set, our analysis is subject to some limitations. First, we only have one outcome measure related to subjective well-being. Our data comes from the BIHS survey was designed by IFPRI and does not have additional measures of SWB. For similar reasons, many other recent studies also employ single measures (e.g. Conzo, Fuochi \& Mencarini, 2017). As argued by Kahneman and Deaton (2010), there are three broad 
measures of SWB: experienced, evaluative, and eudemonic. Life satisfaction scores only capture SWB in the evaluative dimension. In the absence of multiple measures of SWB, however, we are unable to verify the impact of empowerment on other domains of SWB. Second, our analysis is based on survey rather than experimental data. In the absence of a randomized control trial design, we have followed the methodological literature on nonexperimental data based evaluation and used the instrumental variable approach. The findings presented therefore should be revisited in the context of exogenously assigned programs on women's empowerment. In addition, these findings apply to agricultural households and cannot be generalized to women outside the agricultural sector where production and credit relationships between the spouses may well be different. 


\section{References}

Abadian, S. (1996). Women's autonomy and its impact on fertility. World Development, 24(12), 1793-1809.

Ahmed, S.M., Chowdhury, M. \& Bhuiya, A. (2001). Micro-credit and emotional well-being: Experience of poor rural women from Matlab, Bangladesh, World Development, 29 (11), 1957-1966.

Alim, M.A. (2009). Changes in villagers' knowledge, perceptions, and attitudes concerning gender roles and relations in Bangladesh, Development in Practice, 19 (3), 300-310.

Alkire, S., Meinzen-Dick, R., Peterman, A., Quisumbing, A., Seymour, G. \& Vaz, A. (2013a). The women's empowerment in agriculture index, World Development, 52, 71-91.

Alkire, S., Meinzen-Dick, R., Peterman, A., Quisumbing, A.R., Seymour, G. \& Vaz, A. (2013b). The Women's Empowerment in Agriculture Index, OPHI working paper no. 58, Oxford Poverty and Human Development Initiatives (OPHI), University of Oxford.

Amin, R., Ahmed, A.U., Chowdhury, J. \& Ahmed. M. (1994). Poor women's participation in incomegenerating projects and their fertility regulation in rural Bangladesh: Evidence from a recent survey, World Development, 22 (4), 555-566.

Anderson, S. \& Eswaran, M. (2009). What determines female autonomy? Evidence from Bangladesh, Journal of Development Economics, 90(2), 179-191.

Amin, R., Becker, S. \& Bayes, A. (1998). NGO-promoted microcredit programs and women's empowerment in rural Bangladesh: Quantitative and qualitative evidence. Journal of Developing Areas, 32(2), 221236.

Adnan, S. (1993). Birds in a Cage': Institutional Change and Women's Position in Bangladesh, in Nora Federici et al. (eds.) Women's Position and Demographic Change (Oxford: Clarendon Press), 285-318. Asadullah, M. N. \& Chaudhury, N. (2012). Subjective well-being and relative poverty in rural Bangladesh, Journal of Economic Psychology, 33 (5), 940-950.

Asadullah, M.N., Savoia, A. \& Mahmud, W. (2014). Paths to development: Is there a Bangladesh surprise?, World Development, 62, 138-154.

Asadullah, M. N., Xiao, S. \& Yeoh, E. K. (2018). Subjective Well-being in China, 2005-2010: The role of relative income, gender and location, China Economic Review. 48, 83-101. 
Asadullah, M. N. \& Wahhaj, Z. (Forthcoming). Early Marriage, Social Networks and the Transmission of Norms, Economica.

Asadullah, M Niaz \& Wahhaj, Zaki (2016) Missing from the market: Purdah norm and women's paid work participation in Bangladesh. IZA Discussion Papers 10463, Institute for the Study of Labor (IZA).

Balk, D. (1997). Defying gender norms in rural Bangladesh: A social demographic analysis. Population Studies, 51(2):153-172.

Başlevent, C. \& Kirmanoğlu, H. (2017), Gender inequality in Europe and the life satisfaction of working and non-working women, Journal of Happiness Studies, 18(1), 107-24.

Basu, A.M. \& Koolwal, G.B. (2005). Two concepts of female empowerment: Some leads from DHS data on women's status and reproductive health. In: Kishor S, editor. A focus on gender: Collected papers on gender using DHS data. Calverton, MD: ORC Macro; 2005. 15-53.

Bojanowska, A. \& Zalewska, A.M. (2016), Lay understanding of happiness and the experience of wellbeing: Are some conceptions of happiness more beneficial than others?, Journal of Happiness Studies, 17(2), 793-815.

Boye, K. (2009). Relatively Different? How do gender differences in well-being depend on paid and unpaid work in Europe? Social Indicators Research, 93(3), 509-525.

Borgonovi, F. (2008). Doing well by doing good. The relationship between formal volunteering and selfreported health and happiness, Social Science \& Medicine, 66(11), 2321-2334.

Beja, E. L. (2013). Who is happier: Housewife or working wife? Applied Research in Quality of Life, 9(2), 157-177.

Brajša-Žganec, A., Merkaš, M., \& Šverko, I. (2011). Quality of life and leisure activities: How do leisure activities contribute to subjective well-being? Social Indicators Research, 102(1), 81-91.

Camfield, L., Choudhury, K. \& Devine, J. (2009). Well-Being, Happiness, and Why Relationships Matter: Evidence from Bangladesh. Journal of Happiness Studies 10 (1): 71-91.

Chen, L. C., Huq, E. \& D’Souza, S. (1981). Sex bias in the family allocation of food and health care in rural Bangladesh. Population and Development Review 7 (1): 55-70.

Cheung, Y. W., Mok, B. H. \& Cheung, T. S. (2005). Personal empowerment and life satisfaction among 
self-help group members in Hong Kong. Small Group Research 36.3: 354-377.

Clark, A. E. (1997). Job satisfaction and gender: Why are women so happy at work?, Labour Economics, 4(4), 341-372.

Clark, A.E., Frijters, P. \& Shields, M.A. (2008). Relative income, happiness, and utility: an explanation for the Easterlin paradox and other puzzles. Journal of Economic Literature. 46(1):95-144.

Clark, A. E., \& Oswald, A. J. (1996). Satisfaction and Comparison Income Journal of Public Economics, 61, 359-381.

Casiday, R., Kinsman, E. Fisher, C., \& Bambra, C. (2008). Volunteering and Health: What impact does it really have? Report to Volunteering England. London: Volunteering England.

Croson, R. \& Gneezy, U. (2009). Gender differences in preferences, Journal of Economic Literature, 47(2), 448-74.

Cuñado, J. \& Gracia, F. P. (2012). Does education affect happiness? Evidence for Spain, Social Indicators Research, 108(1), 185-196.

Conzo, P., Fuochi, G. \& Mencarini, L. (2017) Fertility and life satisfaction in rural Ethiopia. Demography 54: 1331.

Deaton, A., \& Stone, A. (2014). Evaluative and hedonic wellbeing among those with and without children at home. Proceedings of the National Academy of Sciences, 111, 1328-1333.

Della Giusta, M., Jewell, S.L. \& Kambhampati, U.S. (2011). Gender and life satisfaction in the UK, Feminist Economics, 17 3, 1-34.

Devine, J., Camfield, L. \& Gough, I. (2008). Autonomy or dependence—or both?: Perspectives from Bangladesh, Journal of Happiness Studies, (9), 105-138.

Diener, E., Inglehart, R., \& Tay, L. (2013). Theory and validity of life satisfaction scales. Social Indicators Research, 112(3), 497-527

Duflo, E. (2012). Women empowerment and economic development. Journal of Economic Literature 50 (4), 1051-1079.

Easterlin, R.A. (1974). Does Economic Growth Improve the Human Lot? In Nations and Households in Economic Growth: Essays in Honor of Moses Abramovitz, Academic Press, 89-125. 
Easterlin, R. A., McVey, L. A., Switek, M., Sawangfa, O., \& Zweig, J. S. (2010). The happiness-income paradox revisited. Proceedings of the National Academy of Sciences, 107(52), 22463-22468.

Easterlin, R. A. (2017). Paradox Lost?, Review of Behavioral Economics, 4(4), 311-339.

Fernandez, A., Della Giusta, M. \& Kambhampati, U.S. (2015). The intrinsic value of agency: The case of Indonesia, World Development, 70, 92-107.

Ferrer-i-Carbonell, A. \& Frijters, P. (2004). How important is methodology for the estimate of the determinants of hapiness?, The Economic Journal, 114 497, 641-659.

Feldman, S. (2009). Historicizing garment manufacturing in Bangladesh: Gender, generation, and new regulatory regimes, Journal of International Women's Studies, 11(1), 268-88.

Graham, C. L. \& Nikolova, M. (2015). Bentham or Aristotle in the development process? An empirical investigation of capabilities and subjective well-being, World Development, 68(0), 163-179.

Graham, C., \& Chattopadhyay, S. (2013). Gender and well-being around the world, International Journal of Happiness and Development, 1(2), 212-232.

Groot, W. \& Van Den Brink, H. (2002). Age and education differences in marriages and their effects on life satisfaction, Journal of Happiness Studies, 3(2), 153-165.

Hashemi, S., Schuler, S. \& Riley, A. (1996). Rural credit programs and women's empowerment in Bangladesh, World Development, 24(4): 635-653.

Hossain, N. (2011). Exports, Equity and empowerment: The effects of readymade garments manufacturing employment on gender equality in Bangladesh. Background paper for the WDR 2012.

Heath, R. (2014). Women's access to labor market opportunities, control of household resources, and domestic violence: Evidence from Bangladesh, World Development, 57, 32-46.

Hewett, P. C., Amin, S. \& Sen,, B. (2001). Assessing the impact of garment work on quality of life measures. In Growth of the Garment Industry in Bangladesh: Economic and Social Dimensions, ed. Binayak Sen. Dhaka: UPL Publications.

Herbst, C. M. (2011). 'Paradoxical' decline? Another look at the relative reduction in female happiness, Journal of Economic Psychology, 32(5), 773-788.

Hoddinott, J., \& L. Haddad (1995). Does female income share influence household expenditures? Evidence 
from Cote d'Ivoire, Oxford Bulletin of Economics and Statistics, 57(1): 77-96.

Ibrahim, S., \& Alkire, S. (2007). Agency and empowerment: A proposal for internationally comparable indicators, Oxford Development Studies, 35(4) 379-403.

Iwasaki, Y. (2007). Leisure and quality of life in an international and multicultural context: What are major pathways linking leisure to quality of life? Social Indicators Research, 82, 233-264.

Kabeer, N. (2011). Contextualising the Economic Pathways of Women's Empowerment: Findings from a Multi-country Research Programme, Pathways Policy Paper, Institute of Development Studies, University of Sussex, Brighton, UK, 2011.

Kabeer, N. (2005). Gender equality and women's empowerment: A critical analysis of the third millennium development goal 1, Gender \& Development, 13(1), 13-24.

Kabeer, N. (2011). Between affiliation and autonomy: Navigating pathways of women's empowerment and gender justice in rural Bangladesh, Development and Change, 42(2), 499-528.

Kabeer, N. (1997). Women, Wages and Intrahousehold Power Relations in Urban Bangladesh. Development and Change, 28(2): 261-302.

Kabeer, N. (2001). Bangladeshi women workers and labour market decisions: The power to choose. UPL, Dhaka.

Kahneman, D., \& Deaton, A. (2010). High income improves evaluation of life, but not emotional wellbeing, Proceedings of the National Academy of Sciences, 107 (38) 16489-16493.

Kalyuzhnova, Y. \& Kambhampati, U.S. (2008). The determinants of individual happiness in Kazakhstan, Economic Systems, 32 (3), 285-299.

Khandker, Shahidur R., Bakht, Zaid \& Koolwal, Gayatri B. (2009) The Poverty impact of rural roads: Evidence from Bangladesh, Economic Development and Cultural Change, 57(4), 685-722.

Kotiranta, A., Kovalainen, A. \& Rouvinen, P. (2010). Female leadership and company profitability. in women entrepreneurs and the global environment for growth: A research perspective, ed. Candida G. Brush, Anne de Bruin, Elizabeth J. Gatewood, and Colette Henry. Northampton, MA: Edward Elgar Publishing.

Knight, J., Song, L.N. \& Gunatilaka, R. (2009). Subjective well-being and its determinants in rural China, 
China Economic Review, 20(4), 635-649.

Klugman, J., Hanmer, L., Twigg, S., Hasan, T. \& McCleary-Sills, J. (2014). Voice and Agency: Empowering Women and Girls for Shared Prosperity. Washington, DC: The World Bank.

Lloyd, K. M., \& Auld, C. J. (2002). The role of leisure in determining quality of life: issues of content and measurement, Social Indicators Research, 57, 43-71.

Mahmud, S. (2003). Is Bangladesh Experiencing a "Feminization" of the Labor Force? The Bangladesh Development Studies, 29(1/2), 1-37.

Mahmud, S., Shah, N.M., \& Becker, S. (2012). Measurement of women's empowerment in rural Bangladesh, World Development, 40(3), 610-619.

Matteucci, N. \& Lima, S. V. (2016). Women and happiness, Chapters, in: Handbook of Research Methods and Applications in Happiness and Quality of Life, chapter 19, pages 419-447 Edward Elgar Publishing.

Meisenberg, G. \& Woodley, M. A. (2015). Gender differences in subjective well-being and their relationships with gender equality, Journal of Happiness Studies, 16(6), 1539-1555.

Majlesi, K. (2016). Labor market opportunities and women's decision making power within households, Journal of Development Economics, 119, 34-47.

Murthi, M., Guio, A. C., \& Dreze, J. (1995). Mortality, fertility, and gender bias in India: A district-level analysis, Population and Development Review, 745-782.

Myrskylä, M., \& Margolis, R. (2014). Happiness: Before and after the kids, Demography, 51, 1843-1866.

Naved, R.. T., Azim, S., Bhuiya, A. \& Persson, L. A. (2006). Physical violence by husbands: magnitude, disclosure and help-seeking behavior of women in Bangladesh, Social Science \& Medicine, 62(12), 2917-29.

Ñopo, H. Daza, N. \& Ramos, J. (2012). Gender earning gaps around the world: A study of 64 countries, International Journal of Manpower, 33(5), 464-513.

Pagán, R. (2015). How do leisure activities impact on life satisfaction? Evidence for German people with disabilities. Applied Research in Quality of Life, 10(4), 557-572.

Pearse, R. \& Connell, R. (2016). Gender norms and the economy: Insights from social research, Feminist Economics, 22(1), 30-53. 
Pereznieto, P. \& Taylor, G. (2014). A review of approaches and methods to measure economic empowerment of women and girls, Gender \& Development, 22(2), 233-251.

Pitt, M., Khandker, S. R. \& Cartwright, J. (2006). Empowering women with micro finance: Evidence from Bangladesh, Economic Development and Cultural Change, 54(4), 791-831.

Plagnol, A. \& Easterlin, R. (2008). Aspirations, attainments, and satisfaction: Life cycle differences between American women and men, Journal of Happiness Studies, 9(4), 601-619

Porter, M. (2016). Effects of microcredit and other loans on female empowerment in Bangladesh: The borrower's gender influences intra-household resource allocation, Agricultural Economics, 47(2), 235 245.

Pollmann-Schult, M. (2014). Parenthood and life satisfaction: Why don’t children make people happy? Journal of Marriage and Family, 76, 319-336.

Quisumbing, A. R. \& Maluccio, J. A. (2003). Resources at marriage and intrahousehold allocation: Evidence from Bangladesh, Ethiopia, Indonesia, and South Africa, Oxford Bulletin of Economics and Statistics, 65, 283-327.

Samarakoon, S. \& Parinduri, R. A. (2015). Does education empower women? Evidence from Indonesia, World Development, 66, 428-442.

Samman, E. (2007). Psychological and subjective well-being: A proposal for internationally comparable indicators. Oxford Development Studies, 35(4), 459-486.

Schmiedeberg, C., \& Schröder, J. (2016). Leisure activities and life satisfaction: an analysis with German panel data, Applied Research in Quality of Life, 1-15.

Schuler, S. R. \& Rottach, E. (2010). Women's Empowerment across Generations in Bangladesh, The Journal of Development Studies, 46(3), 379-396.

Schuler, S. R., Hashemi, S. M., Riley, A. P. \& Akhter, S. (1996). Credit programs, patriarchy and men’s violence against women in rural Bangladesh, Social Science \& Medicine 43(12), 1729-42.

Sen, A. (2008). The economics of happiness and capability in Luigino Bruni, Flavio Comim \& Maurizio Pugno (eds.), Capabilities and Happiness. OUP Oxford 16-27.

Sen, A. (2009). Development as Freedom, New York: Anchor Books. 
Senik, C. (2014). Wealth and happiness, Oxford Review of Economic Policy, 30(1), 92-108.

Seymour, G. (2017). Women's empowerment in agriculture: Implications for technical efficiency in rural Bangladesh, Agricultural Economics doi:10.1111/agec.12352

Shilpi, F. (2011). Mobility costs and regional inequality: Evidence from Bangladesh, Journal of Globalization and Development, 2(1), 1-30.

Stevenson, B., \& Wolfers, J. (2009). The paradox of declining female happiness. American Economic Journal: Economic Policy, 1(2), 190-225.

Stewart, F. (2005). Groups and capabilities. Journal of human development, 6(2), 185-204.

Sraboni, E., Malapit, H.J., Quisumbing, A.R. \& Ahmed, A.U. (2014). Women's empowerment in agriculture: What role for food security in Bangladesh?, World Development, 61, 11-52.

Sraboni, E., Quisumbing, A. \& Ahmed, A. U. (2014). How empowered are Bangladeshi women in the agricultural setting? Empirical evidence using a new index, Bangladesh Development Studies, XXXVII (3), 1-25.

Tesch-Römer, C., Motel-Klingebiel, A. \& Tomasik, M.J. (2008), Gender differences in subjective wellbeing: Comparing societies with respect to gender equality, Social Indicators Research, 85(2), 329349.

Thoits, P. A., \& Hewitt, L. N. (2001). Volunteer Work and Well-Being. Journal of Health and Social Behavior, 42, 115-31.

USAID, IFPRI \& OPHI. (2014). Measuring Progress toward Empowerment Women's Empowerment in Agriculture Index: Baseline Report, International Food Policy Research Institute, Washington D.C.

Veenhoven, R. (2010). Capability and happiness: Conceptual difference and reality links, The Journal of Socio-Economics, 39(3), 344-350.

Wang, M., \& Wong, M. S. (2014). Happiness and leisure across countries: Evidence from international survey data. Journal of happiness Studies, 15(1), 85-118. 
Table 1: Component indicators of 5-domain empowerment index, weight distribution, and \% of individuals having adequacy in each component

\begin{tabular}{|c|c|c|c|c|c|}
\hline Domain & Indicators & Definition of indicators & Weight & $\begin{array}{l}\text { Adequacy } \\
\text { - Female }\end{array}$ & $\begin{array}{l}\text { Adequacy } \\
\text { - Male }\end{array}$ \\
\hline \multirow[b]{2}{*}{$\begin{array}{l}\text { Production } \\
\text { decision- } \\
\text { making }\end{array}$} & $\begin{array}{l}\text { Input in production } \\
\text { decisions (i1) }\end{array}$ & $\begin{array}{l}\text { Sole or joint decision making over } \\
\text { food and cash-crop farming, livestock, } \\
\text { and fisheries }\end{array}$ & $1 / 10$ & $51 \%$ & $78 \%$ \\
\hline & $\begin{array}{l}\text { Autonomy in } \\
\text { production (i2) }\end{array}$ & $\begin{array}{l}\text { Autonomy in agricultural production } \\
\text { (e.g., what inputs to buy, crops to } \\
\text { grow, what livestock to raise, etc.). } \\
\text { Reflects the extent to which the } \\
\text { respondent's motivation for decision } \\
\text { making reflects his/her values rather } \\
\text { than a desire to please others or avoid } \\
\text { harm }\end{array}$ & $1 / 10$ & $67 \%$ & $71 \%$ \\
\hline \multirow{3}{*}{$\begin{array}{l}\text { Access to } \\
\text { productive } \\
\text { resources }\end{array}$} & $\begin{array}{l}\text { Ownership of assets } \\
\text { (i3) }\end{array}$ & $\begin{array}{l}\text { Sole or joint ownership of major } \\
\text { household assets }\end{array}$ & $1 / 15$ & $46 \%$ & $97 \%$ \\
\hline & $\begin{array}{l}\text { Purchase, sales, or } \\
\text { transfer of assets (i4) }\end{array}$ & $\begin{array}{l}\text { Whether respondent participates in } \\
\text { decision to buy, sell, or transfer his/her } \\
\text { owned assets }\end{array}$ & $1 / 15$ & $69 \%$ & $98 \%$ \\
\hline & $\begin{array}{l}\text { Access to and } \\
\text { decision on credit } \\
\text { (i5) }\end{array}$ & $\begin{array}{l}\text { Access to and participation in decision } \\
\text { making concerning credit }\end{array}$ & $1 / 15$ & $48 \%$ & $62 \%$ \\
\hline Income & $\begin{array}{l}\text { Control over use of } \\
\text { income (i6) }\end{array}$ & $\begin{array}{l}\text { Sole or joint control over income and } \\
\text { expenditures }\end{array}$ & $1 / 5$ & $85 \%$ & $89 \%$ \\
\hline \multirow[b]{2}{*}{$\begin{array}{l}\text { Community } \\
\text { leadership }\end{array}$} & $\begin{array}{l}\text { Group membership } \\
\text { (i7) }\end{array}$ & $\begin{array}{l}\text { Whether respondent is an active } \\
\text { member in at least one economic or } \\
\text { social group (e.g., agricultural } \\
\text { marketing, credit, water users' groups) }\end{array}$ & $1 / 10$ & $30 \%$ & $14 \%$ \\
\hline & $\begin{array}{l}\text { Speaking in public } \\
\text { (i8) }\end{array}$ & $\begin{array}{l}\text { Whether the respondent is comfortable } \\
\text { speaking in public concerning various } \\
\text { issues such as intervening in a family } \\
\text { dispute, ensure proper payment of } \\
\text { wages for public work programs, etc. }\end{array}$ & $1 / 10$ & $33 \%$ & $66 \%$ \\
\hline \multirow{2}{*}{$\begin{array}{l}\text { Time } \\
\text { allocation }\end{array}$} & Workload (i9) & $\begin{array}{l}\text { Allocation of time to productive and } \\
\text { domestic tasks }\end{array}$ & $1 / 10$ & $18 \%$ & $19 \%$ \\
\hline & Leisure (i10) & $\begin{array}{l}\text { Satisfaction with the available time for } \\
\text { leisure activities }\end{array}$ & $1 / 10$ & $70 \%$ & $74 \%$ \\
\hline $\mathrm{N}$ & & & & 3,860 & 3,860 \\
\hline
\end{tabular}


Table 2: Summary statistics of the variables of interest across full sample and gender subsamples

\begin{tabular}{|c|c|c|c|c|c|c|}
\hline \multirow[t]{2}{*}{ Variables } & \multicolumn{2}{|l|}{ All } & \multicolumn{2}{|l|}{ Female } & \multicolumn{2}{|l|}{ Male } \\
\hline & Mean & SD & Mean & SD & Mean & SD \\
\hline Life satisfaction score & 7.077 & 2.327 & 7.066 & 2.332 & 7.088 & 2.323 \\
\hline Female (yes $=1$, otherwise 0 ) & 0.500 & 0.500 & 1 & 0 & 0 & 0 \\
\hline Age (years) & 41.404 & 13.231 & 37.142 & 11.563 & 45.666 & 13.420 \\
\hline Age squared & 1889.317 & 1204.378 & 1513.181 & 936.777 & 2265.454 & 1319.411 \\
\hline Years of completed schooling & 3.000 & 3.662 & 2.975 & 3.411 & 3.026 & 3.897 \\
\hline Height $(\mathrm{cm})$ & 155.792 & 8.200 & 150.144 & 5.725 & 161.440 & 6.156 \\
\hline Ill in past 4 weeks (yes $=1$, otherwise 0 ) & 0.350 & 0.477 & 0.335 & 0.472 & 0.365 & 0.482 \\
\hline Health disability (yes $=1$, otherwise 0 ) & 0.178 & 0.382 & 0.175 & 0.380 & 0.180 & 0.384 \\
\hline Non-Muslims (yes=1, otherwise 0 ) & 0.114 & 0.318 & 0.114 & 0.318 & 0.114 & 0.318 \\
\hline 5 domain empowerment index & 0.621 & 0.192 & 0.548 & 0.191 & 0.693 & 0.163 \\
\hline Works for pay (yes $=1$, otherwise 0 ) & 0.779 & 0.415 & 0.592 & 0.492 & 0.966 & 0.181 \\
\hline Log of per capita monthly expenditures & 7.097 & 0.540 & 7.097 & 0.540 & 7.097 & 0.540 \\
\hline Female headed HH (yes=1, otherwise 0 ) & 0.001 & 0.032 & 0.001 & 0.032 & 0.001 & 0.032 \\
\hline Number of $0-5$ years child & 0.471 & 0.667 & 0.471 & 0.667 & 0.471 & 0.667 \\
\hline Numbers of 6-14 years child & 0.831 & 0.936 & 0.831 & 0.936 & 0.831 & 0.936 \\
\hline Number of male dependent & 0.033 & 0.181 & 0.033 & 0.181 & 0.033 & 0.181 \\
\hline Number of female dependent & 0.097 & 0.297 & 0.097 & 0.297 & 0.097 & 0.297 \\
\hline Mother-in-law co-resides (yes $=1$, otherwise 0 ) & 0.057 & 0.232 & 0.115 & 0.318 & 0 & 0 \\
\hline Economic shock occurred (yes $=1$, otherwise 0 ) & 0.563 & 0.496 & 0.563 & 0.496 & 0.563 & 0.496 \\
\hline Positive economic event occurred (yes $=1$, otherwise 0 ) & 0.057 & 0.232 & 0.057 & 0.232 & 0.057 & 0.232 \\
\hline Dwelling is broken (yes $=1$, otherwise 0 ) & 0.933 & 0.251 & 0.933 & 0.251 & 0.933 & 0.251 \\
\hline Access to electricity (yes $=1$, otherwise 0 ) & 0.429 & 0.495 & 0.429 & 0.495 & 0.429 & 0.495 \\
\hline $\begin{array}{l}\text { Average number of community activities (based on a list of } 7 \text { specified } \\
\text { activities) participated by others in the community }\end{array}$ & 1.182 & 0.842 & 0.816 & 0.713 & 1.548 & 0.800 \\
\hline $\mathrm{N}$ & 7,720 & & 3,860 & & 3,860 & \\
\hline
\end{tabular}


Table 3: Ordered probit, OLS, fixed effects, and IV estimates of the determinants of life satisfaction

\begin{tabular}{|c|c|c|c|c|c|c|}
\hline & $\begin{array}{c}(1) \\
\text { Ordered. } \\
\text { probit }\end{array}$ & $\begin{array}{c}(2) \\
\text { OLS }\end{array}$ & $\begin{array}{l}\text { (3) } \\
\mathrm{HH} \\
\mathrm{FE}\end{array}$ & $\begin{array}{l}\text { (4) } \\
\text { Community } \\
\text { FE }\end{array}$ & $\begin{array}{l}\text { (5) } \\
\text { IV } \\
\text { (First } \\
\text { stage) }\end{array}$ & $\begin{array}{l}\text { (6) } \\
\text { IV } \\
\text { (Second } \\
\text { stage) }\end{array}$ \\
\hline 5-domain empowerment index & $\begin{array}{c}1.432 * * * \\
(0.109)\end{array}$ & $\begin{array}{c}2.979 * * * \\
(0.223)\end{array}$ & $\begin{array}{c}1.246 * * * \\
(0.295)\end{array}$ & $\begin{array}{c}2.435 * * * \\
(0.225)\end{array}$ & & $\begin{array}{c}4.439 * * * \\
(0.646)\end{array}$ \\
\hline Female $(=1$, otherwise 0$)$ & $\begin{array}{l}0.218^{* *} \\
(0.093)\end{array}$ & $\begin{array}{c}0.444^{* *} \\
(0.196)\end{array}$ & $\begin{array}{c}0.199 \\
(0.246)\end{array}$ & $\begin{array}{c}0.463^{* *} \\
(0.196)\end{array}$ & $\begin{array}{c}-0.073^{* * *} \\
(0.006)\end{array}$ & $\begin{array}{c}0.572^{* * *} \\
(0.107)\end{array}$ \\
\hline Empowerment index ${ }^{*}$ female & $\begin{array}{l}-0.039 \\
(0.137)\end{array}$ & $\begin{array}{l}-0.056 \\
(0.282)\end{array}$ & $\begin{array}{c}0.178 \\
(0.327)\end{array}$ & $\begin{array}{l}-0.302 \\
(0.285)\end{array}$ & & \\
\hline Age (years) & $\begin{array}{l}-0.002 \\
(0.006)\end{array}$ & $\begin{array}{l}-0.003 \\
(0.013)\end{array}$ & $\begin{array}{c}0.029 \\
(0.026)\end{array}$ & $\begin{array}{c}0.019 \\
(0.012)\end{array}$ & $\begin{array}{c}0.008^{* * *} \\
(0.001)\end{array}$ & $\begin{array}{l}-0.016 \\
(0.014)\end{array}$ \\
\hline Age squared & $\begin{array}{l}-0.000 \\
(0.000)\end{array}$ & $\begin{array}{l}-0.000 \\
(0.000)\end{array}$ & $\begin{array}{l}-0.000 \\
(0.000)\end{array}$ & $\begin{array}{c}-0.000^{* *} \\
(0.000)\end{array}$ & $\begin{array}{c}-0.000^{* * *} \\
(0.000)\end{array}$ & $\begin{array}{c}0.000 \\
(0.000)\end{array}$ \\
\hline Years of completed schooling & $\begin{array}{c}0.018^{* * *} \\
(0.004)\end{array}$ & $\begin{array}{c}0.039 * * * \\
(0.007)\end{array}$ & $\begin{array}{c}0.002 \\
(0.014)\end{array}$ & $\begin{array}{c}0.040^{* * * *} \\
(0.008)\end{array}$ & $\begin{array}{c}0.005 * * * \\
(0.001)\end{array}$ & $\begin{array}{c}0.031^{* * *} \\
(0.008)\end{array}$ \\
\hline Height $(\mathrm{cm})$ & $\begin{array}{c}0.003 \\
(0.002)\end{array}$ & $\begin{array}{c}0.005 \\
(0.004)\end{array}$ & $\begin{array}{c}0.001 \\
(0.006)\end{array}$ & $\begin{array}{c}0.002 \\
(0.004)\end{array}$ & $\begin{array}{c}0.001 * * * \\
(0.000)\end{array}$ & $\begin{array}{c}0.003 \\
(0.004)\end{array}$ \\
\hline III in past 4 weeks (yes $=1$, otherwise 0 ) & $\begin{array}{l}-0.028 \\
(0.026)\end{array}$ & $\begin{array}{l}-0.060 \\
(0.055)\end{array}$ & $\begin{array}{c}0.032 \\
(0.079)\end{array}$ & $\begin{array}{l}-0.064 \\
(0.055)\end{array}$ & $\begin{array}{l}0.007^{*} \\
(0.004)\end{array}$ & $\begin{array}{l}-0.087 \\
(0.056)\end{array}$ \\
\hline Health disability (yes $=1$, otherwise 0 ) & $\begin{array}{c}-0.100^{* * *} \\
(0.035)\end{array}$ & $\begin{array}{c}-0.182^{* *} \\
(0.074)\end{array}$ & $\begin{array}{l}-0.065 \\
(0.113)\end{array}$ & $\begin{array}{l}-0.110 \\
(0.072)\end{array}$ & $\begin{array}{c}-0.013^{* *} \\
(0.006)\end{array}$ & $\begin{array}{c}-0.164^{* *} \\
(0.075)\end{array}$ \\
\hline Non-Muslim (yes=1, otherwise 0 ) & $\begin{array}{l}-0.040 \\
(0.038)\end{array}$ & $\begin{array}{l}-0.100 \\
(0.080)\end{array}$ & & $\begin{array}{l}-0.113 \\
(0.122)\end{array}$ & $\begin{array}{c}0.012^{* *} \\
(0.006)\end{array}$ & $\begin{array}{l}-0.118 \\
(0.081)\end{array}$ \\
\hline Works for pay (yes $=1$, otherwise 0 ) & $\begin{array}{c}0.018 \\
(0.033)\end{array}$ & $\begin{array}{c}0.027 \\
(0.068)\end{array}$ & $\begin{array}{l}-0.032 \\
(0.087)\end{array}$ & $\begin{array}{l}-0.028 \\
(0.070)\end{array}$ & $\begin{array}{c}0.019 * * * \\
(0.006)\end{array}$ & $\begin{array}{c}0.000 \\
(0.069)\end{array}$ \\
\hline Log of per capita monthly expenditures & $\begin{array}{c}0.195 * * * \\
(0.026)\end{array}$ & $\begin{array}{c}0.406 * * * \\
(0.053)\end{array}$ & & $\begin{array}{c}0.411^{* * *} \\
(0.055)\end{array}$ & $\begin{array}{c}0.003 \\
(0.004)\end{array}$ & $\begin{array}{c}0.403^{* * *} \\
(0.053)\end{array}$ \\
\hline Female headed $\mathrm{HH}$ (yes $=1$, otherwise 0 ) & $\begin{array}{l}-0.560 \\
(0.543)\end{array}$ & $\begin{array}{l}-1.231 \\
(1.185)\end{array}$ & & $\begin{array}{l}-1.453^{*} \\
(0.777)\end{array}$ & $\begin{array}{c}0.051 \\
(0.079)\end{array}$ & $\begin{array}{l}-1.338 \\
(1.196)\end{array}$ \\
\hline Number of $0-5$ years child & $\begin{array}{l}-0.037^{*} \\
(0.021)\end{array}$ & $\begin{array}{l}-0.081^{*} \\
(0.044)\end{array}$ & & $\begin{array}{l}-0.066 \\
(0.046)\end{array}$ & $\begin{array}{c}-0.008^{* *} \\
(0.003)\end{array}$ & $\begin{array}{l}-0.067 \\
(0.045)\end{array}$ \\
\hline Number of 6-14 years child & $\begin{array}{c}-0.036^{* *} \\
(0.014)\end{array}$ & $\begin{array}{c}-0.080^{* * *} \\
(0.030)\end{array}$ & & $\begin{array}{c}-0.063^{* *} \\
(0.030)\end{array}$ & $\begin{array}{c}0.005^{* *} \\
(0.002)\end{array}$ & $\begin{array}{c}-0.086 * * * \\
(0.030)\end{array}$ \\
\hline Number of male dependent & $\begin{array}{c}0.082 \\
(0.062)\end{array}$ & $\begin{array}{c}0.175 \\
(0.128)\end{array}$ & & $\begin{array}{c}0.206 \\
(0.140)\end{array}$ & $\begin{array}{c}0.006 \\
(0.010)\end{array}$ & $\begin{array}{c}0.164 \\
(0.129)\end{array}$ \\
\hline Number of female dependent & $\begin{array}{c}0.041 \\
(0.048)\end{array}$ & $\begin{array}{c}0.083 \\
(0.099)\end{array}$ & & $\begin{array}{c}0.118 \\
(0.101)\end{array}$ & $\begin{array}{c}0.023^{* * *} \\
(0.007)\end{array}$ & $\begin{array}{c}0.052 \\
(0.101)\end{array}$ \\
\hline Mother-in-law co-resides (yes $=1$, otherwise 0 ) & $\begin{array}{c}0.074 \\
(0.064)\end{array}$ & $\begin{array}{c}0.140 \\
(0.131)\end{array}$ & $\begin{array}{c}0.020 \\
(0.147)\end{array}$ & $\begin{array}{c}0.162 \\
(0.131)\end{array}$ & $\begin{array}{c}-0.030^{* * *} \\
(0.011)\end{array}$ & $\begin{array}{c}0.186 \\
(0.135)\end{array}$ \\
\hline Economic shock occurred, (yes $=1$, otherwise 0 ) & $\begin{array}{l}-0.023 \\
(0.024)\end{array}$ & $\begin{array}{l}-0.063 \\
(0.050)\end{array}$ & & $\begin{array}{c}-0.219 * * * \\
(0.054)\end{array}$ & $\begin{array}{c}0.003 \\
(0.004)\end{array}$ & $\begin{array}{l}-0.064 \\
(0.050)\end{array}$ \\
\hline Positive economic event occurred (yes $=1$, otherwise 0 ) & $\begin{array}{c}0.275 * * * \\
(0.056)\end{array}$ & $\begin{array}{c}0.550^{* * *} \\
(0.108)\end{array}$ & & $\begin{array}{c}0.360^{* * *} \\
(0.109)\end{array}$ & $\begin{array}{l}0.019 * * \\
(0.009)\end{array}$ & $\begin{array}{c}0.519^{* * *} \\
(0.110)\end{array}$ \\
\hline Dwelling is broken (yes $=1$, otherwise 0 ) & $\begin{array}{c}-0.344^{* * *} \\
(0.054)\end{array}$ & $\begin{array}{c}-0.652^{* * *} \\
(0.100)\end{array}$ & & $\begin{array}{c}-0.552^{* * *} \\
(0.104)\end{array}$ & $\begin{array}{l}-0.003 \\
(0.008)\end{array}$ & $\begin{array}{c}-0.662^{* * *} \\
(0.102)\end{array}$ \\
\hline Access to electricity (yes $=1$, otherwise 0 ) & $\begin{array}{c}0.107^{* * *} \\
(0.026)\end{array}$ & $\begin{array}{c}0.220 * * * \\
(0.053)\end{array}$ & & $\begin{array}{c}0.203^{* * *} \\
(0.063)\end{array}$ & $\begin{array}{c}0.021 * * * \\
(0.004)\end{array}$ & $\begin{array}{c}0.184^{* * *} \\
(0.055)\end{array}$ \\
\hline $\begin{array}{l}\text { Excluded instrument } \\
\text { Average number of community activities participated by others in } \\
\text { the community }\end{array}$ & & & & & $\begin{array}{c}0.052^{* * *} \\
(0.003)\end{array}$ & \\
\hline Constant & & $\begin{array}{c}1.263 \\
(0.852) \\
\end{array}$ & $\begin{array}{c}5.041^{* * *} \\
(1.217) \\
\end{array}$ & $\begin{array}{c}2.377^{* * *} \\
(0.834) \\
\end{array}$ & $\begin{array}{c}0.181^{* * *} \\
(0.063)\end{array}$ & $\begin{array}{c}0.961 \\
(0.862) \\
\end{array}$ \\
\hline $\mathrm{N}$ & 7,720 & 7,720 & 7,720 & 7,720 & 7,720 & 7,720 \\
\hline R-squared/ Pseudo $\mathrm{R}^{2}$ & 0.035 & 0.130 & 0.011 & 0.071 & & 0.118 \\
\hline Under ID test (p-value), H0: under identified & & & & & & 0.000 \\
\hline Weak ID test stat (Kleibergen-Paap rk Wald F) & & & & & & 412.6 \\
\hline Anderson-Rubin test (p-value), H0: Endogenous variable irrelevant & & & & & & 45.30 \\
\hline Endogeneity test (p-value), H0: exogenous & & & & & & 0.017 \\
\hline
\end{tabular}

Note: (1) Robust standard errors in parentheses (2) *** $\mathrm{p}<0.01, * * \mathrm{p}<0.05, * \mathrm{p}<0.1$ (3) fixed effects estimates are based on OLS regression. (4) Community is defined at Union level. . (5) Regression model also include division dummies. 
Table 4: Ordered probit, OLS, fixed effects and IV estimates of the determinants of life satisfaction: female subsample

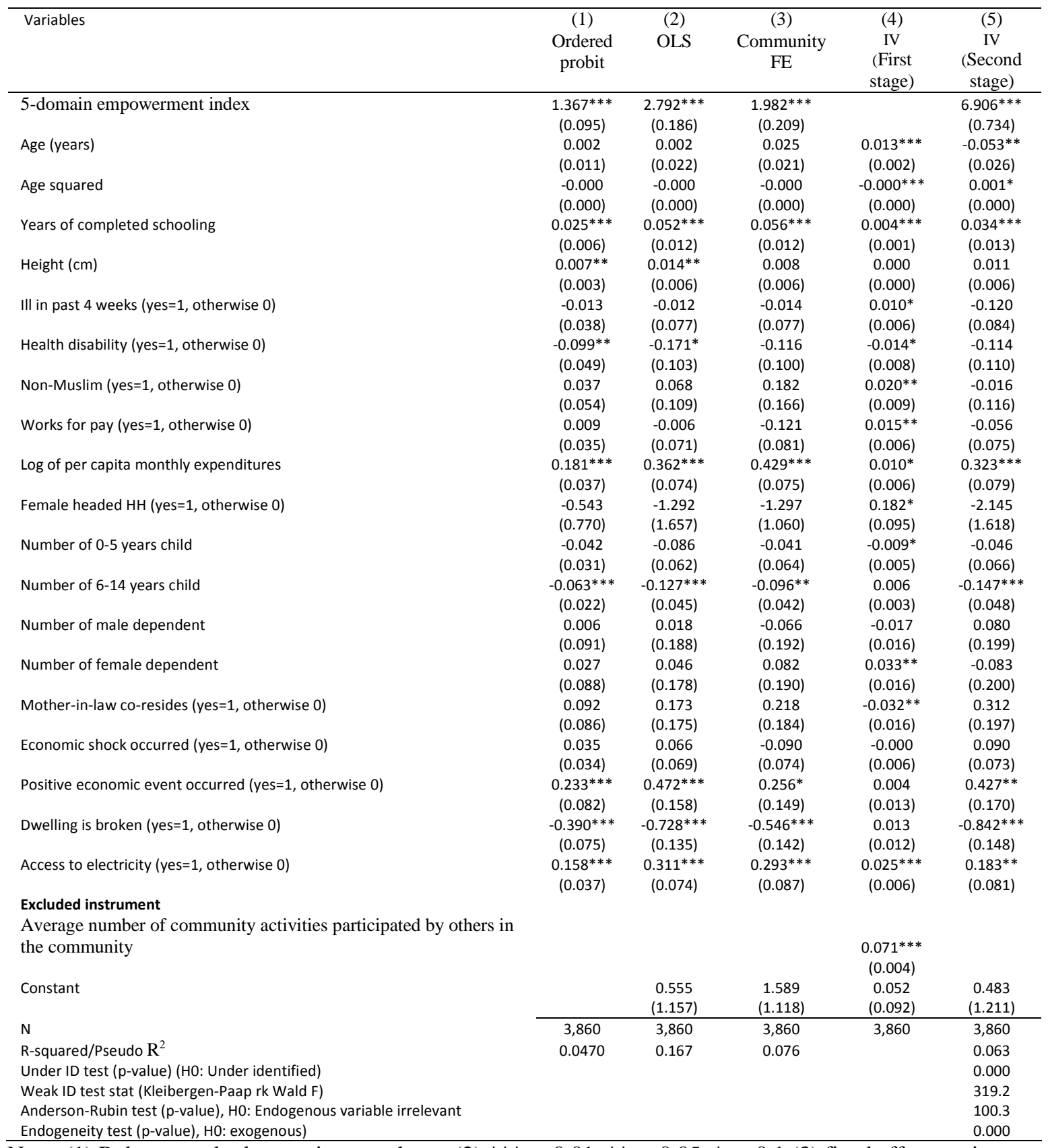

Note: (1) Robust standard errors in parentheses (2) *** $\mathrm{p}<0.01, * * \mathrm{p}<0.05,{ }^{*} \mathrm{p}<0.1$ (3) fixed effects estimates are based on OLS regression. (4) Community is defined at Union level. . (5) Regression model also include division dummies. 
Table 5: Ordered probit, OLS, fixed effects and IV estimates of the determinants of life satisfaction:

male subsample

\begin{tabular}{|c|c|c|c|c|c|}
\hline Variables & $\begin{array}{c}(1) \\
\text { Ordered } \\
\text { probit }\end{array}$ & $\begin{array}{c}\text { (2) } \\
\text { OLS }\end{array}$ & $\begin{array}{c}(3) \\
\text { Commu } \\
\text { nity FE }\end{array}$ & $\begin{array}{c}\text { (4) } \\
\text { IV (First } \\
\text { stage) }\end{array}$ & $\begin{array}{c}\text { (5) } \\
\text { IV (Second } \\
\text { stage) }\end{array}$ \\
\hline 5-domain empowerment index & $\begin{array}{c}1.552^{* * *} \\
(0.112)\end{array}$ & $\begin{array}{c}3.241^{* * *} \\
(0.231)\end{array}$ & $\begin{array}{c}2.839 * * * \\
(0.243)\end{array}$ & & $\begin{array}{c}0.783 \\
(1.201)\end{array}$ \\
\hline Age (years) & $\begin{array}{l}-0.013 \\
(0.009)\end{array}$ & $\begin{array}{l}-0.023 \\
(0.019)\end{array}$ & $\begin{array}{c}0.005 \\
(0.018)\end{array}$ & $\begin{array}{c}0.008^{* * *} \\
(0.001)\end{array}$ & $\begin{array}{l}-0.004 \\
(0.022)\end{array}$ \\
\hline Age squared & $\begin{array}{c}0.000 \\
(0.000)\end{array}$ & $\begin{array}{c}0.000 \\
(0.000)\end{array}$ & $\begin{array}{l}-0.000 \\
(0.000)\end{array}$ & $\begin{array}{c}-0.000^{* * *} \\
(0.000)\end{array}$ & $\begin{array}{l}-0.000 \\
(0.000)\end{array}$ \\
\hline Years of completed schooling & $\begin{array}{c}0.016^{* * *} \\
(0.005)\end{array}$ & $\begin{array}{c}0.035^{* * *} \\
(0.010)\end{array}$ & $\begin{array}{c}0.033^{* * *} \\
(0.010)\end{array}$ & $\begin{array}{c}0.006^{* * *} \\
(0.001)\end{array}$ & $\begin{array}{c}0.050^{* * *} \\
(0.012)\end{array}$ \\
\hline Height $(\mathrm{cm})$ & $\begin{array}{l}-0.001 \\
(0.003)\end{array}$ & $\begin{array}{l}-0.003 \\
(0.006)\end{array}$ & $\begin{array}{l}-0.002 \\
(0.006)\end{array}$ & $\begin{array}{c}0.001^{* * *} \\
(0.000)\end{array}$ & $\begin{array}{c}0.001 \\
(0.006)\end{array}$ \\
\hline III in past 4 weeks (yes $=1$, otherwise 0 ) & $\begin{array}{l}-0.036 \\
(0.037)\end{array}$ & $\begin{array}{l}-0.087 \\
(0.077)\end{array}$ & $\begin{array}{l}-0.062 \\
(0.076)\end{array}$ & $\begin{array}{c}0.002 \\
(0.005)\end{array}$ & $\begin{array}{l}-0.063 \\
(0.079)\end{array}$ \\
\hline Health disability (yes $=1$, otherwise 0 ) & $\begin{array}{l}-0.096^{*} \\
(0.050)\end{array}$ & $\begin{array}{l}-0.176^{*} \\
(0.104)\end{array}$ & $\begin{array}{l}-0.024 \\
(0.101)\end{array}$ & $\begin{array}{l}-0.010 \\
(0.007)\end{array}$ & $\begin{array}{l}-0.199^{*} \\
(0.105)\end{array}$ \\
\hline Non-Muslim (yes=1, otherwise 0 ) & $\begin{array}{c}-0.115^{* *} \\
(0.055)\end{array}$ & $\begin{array}{c}-0.261^{* *} \\
(0.115)\end{array}$ & $\begin{array}{c}-0.419^{* *} \\
(0.167)\end{array}$ & $\begin{array}{c}0.002 \\
(0.007)\end{array}$ & $\begin{array}{c}-0.256^{* *} \\
(0.117)\end{array}$ \\
\hline Works for pay (yes $=1$, otherwise 0 ) & $\begin{array}{l}0.190^{*} \\
(0.114)\end{array}$ & $\begin{array}{l}0.411^{*} \\
(0.237)\end{array}$ & $\begin{array}{c}0.536 * * * \\
(0.197)\end{array}$ & $\begin{array}{l}0.029^{*} \\
(0.016)\end{array}$ & $\begin{array}{l}0.484^{*} \\
(0.250)\end{array}$ \\
\hline Log of per capita monthly expenditures & $\begin{array}{c}0.216^{* * *} \\
(0.036)\end{array}$ & $\begin{array}{c}0.450^{* * *} \\
(0.074)\end{array}$ & $\begin{array}{c}0.394 * * * \\
(0.076)\end{array}$ & $\begin{array}{l}-0.004 \\
(0.005)\end{array}$ & $\begin{array}{c}0.435 * * * \\
(0.075)\end{array}$ \\
\hline Female headed $\mathrm{HH}$ (yes $=1$, otherwise 0 ) & $\begin{array}{l}-0.612 \\
(0.749)\end{array}$ & $\begin{array}{l}-1.242 \\
(1.647)\end{array}$ & $\begin{array}{l}-1.552 \\
(1.072)\end{array}$ & $\begin{array}{l}-0.074 \\
(0.094)\end{array}$ & $\begin{array}{l}-1.398 \\
(1.568)\end{array}$ \\
\hline Number of $0-5$ years child & $\begin{array}{l}-0.033 \\
(0.030)\end{array}$ & $\begin{array}{l}-0.076 \\
(0.063)\end{array}$ & $\begin{array}{l}-0.098 \\
(0.063)\end{array}$ & $\begin{array}{l}-0.006 \\
(0.004)\end{array}$ & $\begin{array}{l}-0.096 \\
(0.064)\end{array}$ \\
\hline Number of 6-14 years child & $\begin{array}{l}-0.005 \\
(0.020)\end{array}$ & $\begin{array}{l}-0.016 \\
(0.042)\end{array}$ & $\begin{array}{l}-0.025 \\
(0.042)\end{array}$ & $\begin{array}{l}-0.001 \\
(0.003)\end{array}$ & $\begin{array}{l}-0.020 \\
(0.043)\end{array}$ \\
\hline Number of male dependent & $\begin{array}{l}0.145^{*} \\
(0.086)\end{array}$ & $\begin{array}{l}0.304^{*} \\
(0.175)\end{array}$ & $\begin{array}{c}0.440^{* *} \\
(0.192)\end{array}$ & $\begin{array}{c}0.030 * * \\
(0.012)\end{array}$ & $\begin{array}{c}0.379 * * \\
(0.177)\end{array}$ \\
\hline Number of female dependent & $\begin{array}{c}0.045 \\
(0.058)\end{array}$ & $\begin{array}{c}0.092 \\
(0.120)\end{array}$ & $\begin{array}{c}0.100 \\
(0.118)\end{array}$ & $\begin{array}{l}0.014^{*} \\
(0.008)\end{array}$ & $\begin{array}{c}0.121 \\
(0.122)\end{array}$ \\
\hline Mother-in-law co-resides (yes $=1$, otherwise 0 ) & & & & & \\
\hline Economic shock occurred (yes $=1$, otherwise 0 ) & $\begin{array}{c}-0.080^{* *} \\
(0.034)\end{array}$ & $\begin{array}{c}-0.190 * * * \\
(0.071)\end{array}$ & $\begin{array}{c}-0.348^{* * *} \\
(0.075)\end{array}$ & $\begin{array}{c}0.008 \\
(0.005)\end{array}$ & $\begin{array}{c}-0.170 * * \\
(0.073)\end{array}$ \\
\hline Positive economic event occurred (yes $=1$, otherwise 0 ) & $\begin{array}{c}0.316^{* * *} \\
(0.078)\end{array}$ & $\begin{array}{c}0.617^{* * *} \\
(0.146)\end{array}$ & $\begin{array}{c}0.450 * * * \\
(0.150)\end{array}$ & $\begin{array}{c}0.033^{* * *} \\
(0.011)\end{array}$ & $\begin{array}{c}0.696 * * * \\
(0.155)\end{array}$ \\
\hline Dwelling is broken (yes $=1$, otherwise 0 ) & $\begin{array}{c}-0.304^{* * *} \\
(0.077)\end{array}$ & $\begin{array}{c}-0.576^{* * *} \\
(0.146)\end{array}$ & $\begin{array}{c}-0.561^{* * *} \\
(0.143)\end{array}$ & $\begin{array}{c}-0.021^{* *} \\
(0.009)\end{array}$ & $\begin{array}{c}-0.614 * * * \\
(0.149)\end{array}$ \\
\hline Access to electricity (yes $=1$, otherwise 0 ) & $\begin{array}{l}0.060^{*} \\
(0.036)\end{array}$ & $\begin{array}{l}0.126^{*} \\
(0.075)\end{array}$ & $\begin{array}{c}0.103 \\
(0.087)\end{array}$ & $\begin{array}{c}0.015^{* * *} \\
(0.005)\end{array}$ & $\begin{array}{c}0.167^{* *} \\
(0.078)\end{array}$ \\
\hline Excluded instrument & & & & & \\
\hline Average number of community activities participated by others in the community & & & & $\begin{array}{c}0.039 * * * \\
(0.003)\end{array}$ & \\
\hline Constant & & $\begin{array}{l}2.209^{*} \\
(1.204)\end{array}$ & $\begin{array}{c}2.849 * * \\
(1.166)\end{array}$ & $\begin{array}{c}0.178^{* *} \\
(0.083)\end{array}$ & $\begin{array}{c}2.771^{* *} \\
(1.249)\end{array}$ \\
\hline $\mathrm{N}$ & 3,860 & 3,860 & 3,860 & 3,860 & 3,860 \\
\hline R-squared/Pseudo $\mathrm{R}^{2}$ & 0.034 & 0.123 & 0.088 & & 0.096 \\
\hline Under ID test ( $p$-value) (HO: Under identified) & & & & & 0.000 \\
\hline Weak ID test stat (Kleibergen-Paap rk Wald F) & & & & & 150.9 \\
\hline Anderson-Rubin test ( $p$-value), HO: Endogenous variable irrelevant & & & & & 0.413 \\
\hline Endogeneity test (p-value), HO: exogenous) & & & & & 0.033 \\
\hline
\end{tabular}

Note: (1) Robust standard errors in parentheses (2) *** p $<0.01, * * \mathrm{p}<0.05, * \mathrm{p}<0.1$ (3) fixed effects estimates are based on OLS regression. (4) Community is defined at Union level. (5) Regression model also include division dummies. 
Table 6: Ordered probit estimates of the determinants of life satisfaction, subsamples estimates

\begin{tabular}{|c|c|c|c|c|c|c|c|}
\hline Variables & $\begin{array}{l}\text { Poorest } \\
\text { quartile }\end{array}$ & $\begin{array}{l}\text { Richest } \\
\text { quartile }\end{array}$ & Muslims & Non-Muslims & $\begin{array}{c}\text { Integrated } \\
\text { zone }\end{array}$ & $\begin{array}{l}\text { Non-integrated } \\
\text { zone (southern } \\
\text { districts) }\end{array}$ & $\begin{array}{c}\text { Non-integrated } \\
\text { zone (northern } \\
\text { districts) }\end{array}$ \\
\hline \multirow{2}{*}{ 5-domain empowerment index } & $1.540^{* * *}$ & $1.050^{* * *}$ & $1.419^{* * *}$ & $1.590^{* * *}$ & $1.570^{* * *}$ & $1.233^{* * *}$ & $1.356^{* * *}$ \\
\hline & $(0.215)$ & (0.249) & $(0.114)$ & $(0.357)$ & $(0.144)$ & $(0.230)$ & (0.249) \\
\hline \multirow[t]{2}{*}{ Female $(=1$, otherwise 0$)$} & $0.470^{* * *}$ & -0.103 & $0.195^{* *}$ & 0.467 & $0.412^{* * *}$ & 0.186 & -0.170 \\
\hline & $(0.177)$ & $(0.217)$ & $(0.098)$ & $(0.301)$ & $(0.130)$ & $(0.190)$ & $(0.202)$ \\
\hline \multirow[t]{2}{*}{ Empowerment index*female } & -0.390 & 0.465 & -0.012 & -0.300 & -0.114 & -0.196 & 0.403 \\
\hline & $(0.271)$ & (0.298) & $(0.144)$ & $(0.436)$ & $(0.191)$ & $(0.268)$ & $(0.306)$ \\
\hline \multirow[t]{2}{*}{ Log of per capita monthly expenditures } & $0.208^{* * *}$ & $0.178^{* * *}$ & $0.195^{* * *}$ & $0.179^{* *}$ & $0.216^{* * *}$ & $0.139^{* * *}$ & $0.161^{* * *}$ \\
\hline & $(0.053)$ & $(0.049)$ & $(0.027)$ & $(0.082)$ & $(0.036)$ & $(0.050)$ & $(0.053)$ \\
\hline $\mathrm{N}$ & 1,946 & 1,892 & 6,838 & 882 & 3,768 & 2,210 & 1,742 \\
\hline Pseudo $\mathrm{R}^{2}$ & 0.033 & 0.033 & 0.035 & 0.047 & 0.044 & 0.023 & 0.055 \\
\hline Log-likelihood & -3792 & -3388 & -12828 & -1675 & -7001 & -4137 & -3196 \\
\hline $\mathrm{Chi}^{2}$ & 1406 & 246.700 & 963.500 & 184.300 & 634.400 & 197.500 & 377.800 \\
\hline
\end{tabular}

Note: (1) Robust standard errors in parentheses $* * * \mathrm{p}<0.01, * * \mathrm{p}<0.05,{ }^{*} \mathrm{p}<0.1$ (2) All regressions include the same set of additional controls as in column 1 of table 3. 
Table 7: Ordered probit estimates of the determinants of life satisfaction -component indicators of empowerment index interacted with female

\begin{tabular}{|c|c|c|c|c|c|c|c|c|c|c|c|}
\hline & (1) & (2) & (3) & (4) & (5) & (6) & (7) & (8) & (9) & (10) & \\
\hline Female (yes $=1$, otherwise 0 ) & $\begin{array}{c}0.169^{* * *} \\
(0.043)\end{array}$ & $\begin{array}{c}0.045 \\
(0.042)\end{array}$ & $\begin{array}{c}0.145^{* * *} \\
(0.043)\end{array}$ & $\begin{array}{c}0.115^{* * *} \\
(0.040)\end{array}$ & $\begin{array}{c}0.129^{* * *} \\
(0.044)\end{array}$ & $\begin{array}{c}0.034 \\
(0.040)\end{array}$ & $\begin{array}{c}-0.063 \\
(0.066)\end{array}$ & $\begin{array}{c}0.025 \\
(0.048)\end{array}$ & $\begin{array}{c}0.009 \\
(0.069)\end{array}$ & $\begin{array}{c}0.065 \\
(0.042)\end{array}$ & \\
\hline Component indicator*female & $\begin{array}{c}-0.183^{* * *} \\
(0.053)\end{array}$ & $\begin{array}{l}-0.036 \\
(0.052)\end{array}$ & $\begin{array}{c}0.059 \\
(0.103)\end{array}$ & $\begin{array}{c}0.103 \\
(0.131)\end{array}$ & $\begin{array}{c}-0.180^{* * *} \\
(0.049)\end{array}$ & $\begin{array}{l}-0.034 \\
(0.069)\end{array}$ & $\begin{array}{l}0.105 \\
(0.065)\end{array}$ & $\begin{array}{c}0.028 \\
(0.051)\end{array}$ & $\begin{array}{c}0.078 \\
(0.069)\end{array}$ & $\begin{array}{l}0.027 \\
(0.051)\end{array}$ & \\
\hline \multicolumn{12}{|l|}{ Component indicator } \\
\hline i1 Input in production decision (=1, otherwise 0 ) & $\begin{array}{c}0.213^{* * *} \\
(0.042)\end{array}$ & & & & & & & & & & \\
\hline i2 Able to act on own values $(=1$, otherwise 0$)$ & & $\begin{array}{c}0.276^{* * *} \\
(0.038)\end{array}$ & & & & & & & & & \\
\hline i3 Own asset (=1, otherwise 0 ) & & & $\begin{array}{c}0.286^{* * *} \\
(0.097)\end{array}$ & & & & & & & & \\
\hline i4 Input in buy/sell/transfer of asset (=1, otherwise 0 ) & & & & $\begin{array}{c}0.408^{* * *} \\
(0.126)\end{array}$ & & & & & & & \\
\hline i5 Input in borrowed money usage $(=1$, otherwise 0$)$ & & & & & $\begin{array}{l}-0.030 \\
(0.036)\end{array}$ & & & & & & \\
\hline i6 Input in decision on use of income $(=1$, otherwise 0$)$ & & & & & & $\begin{array}{c}0.366^{* * *} \\
(0.051)\end{array}$ & & & & & \\
\hline i7 Member in a group ( $=1$, otherwise 0 ) & & & & & & & $\begin{array}{c}0.159 * * * \\
(0.053)\end{array}$ & & & & \\
\hline i8 Comfortable in public speaking $(=1$, otherwise 0 ) & & & & & & & & $\begin{array}{c}0.013 \\
(0.037)\end{array}$ & & & \\
\hline ig Works less than 10.5 hours in a day $(=1$, otherwise 0$)$ & & & & & & & & & $\begin{array}{c}0.014 \\
(0.052)\end{array}$ & & \\
\hline i10 Satisfied with leisure (=1, otherwise 0 ) & & & & & & & & & & $\begin{array}{c}0.541^{* * *} \\
(0.038)\end{array}$ & \\
\hline Observations & 7,720 & 7,720 & 7,720 & 7,720 & 7,720 & 7,720 & 7,720 & 7,720 & 7,720 & 7,720 & \\
\hline Pseudo $\mathrm{R}^{2}$ & 0.0275 & 0.0264 & 0.0240 & 0.0248 & 0.0229 & 0.0261 & 0.0226 & 0.0222 & 0.0225 & 0.0346 & \\
\hline Log-likelihood & -14643 & -14660 & -14696 & -14684 & -14713 & -14665 & -14716 & -14722 & -14719 & -14536 & \\
\hline $\mathrm{Chi}^{2}$ & 877.6 & 834.7 & 777.9 & 814.3 & 750.1 & 861.3 & 743.5 & 732.3 & 739.3 & 1081 & \\
\hline
\end{tabular}


Appendix Table A: IV estimates of the determinants of life satisfaction based on alternative

\section{instruments}

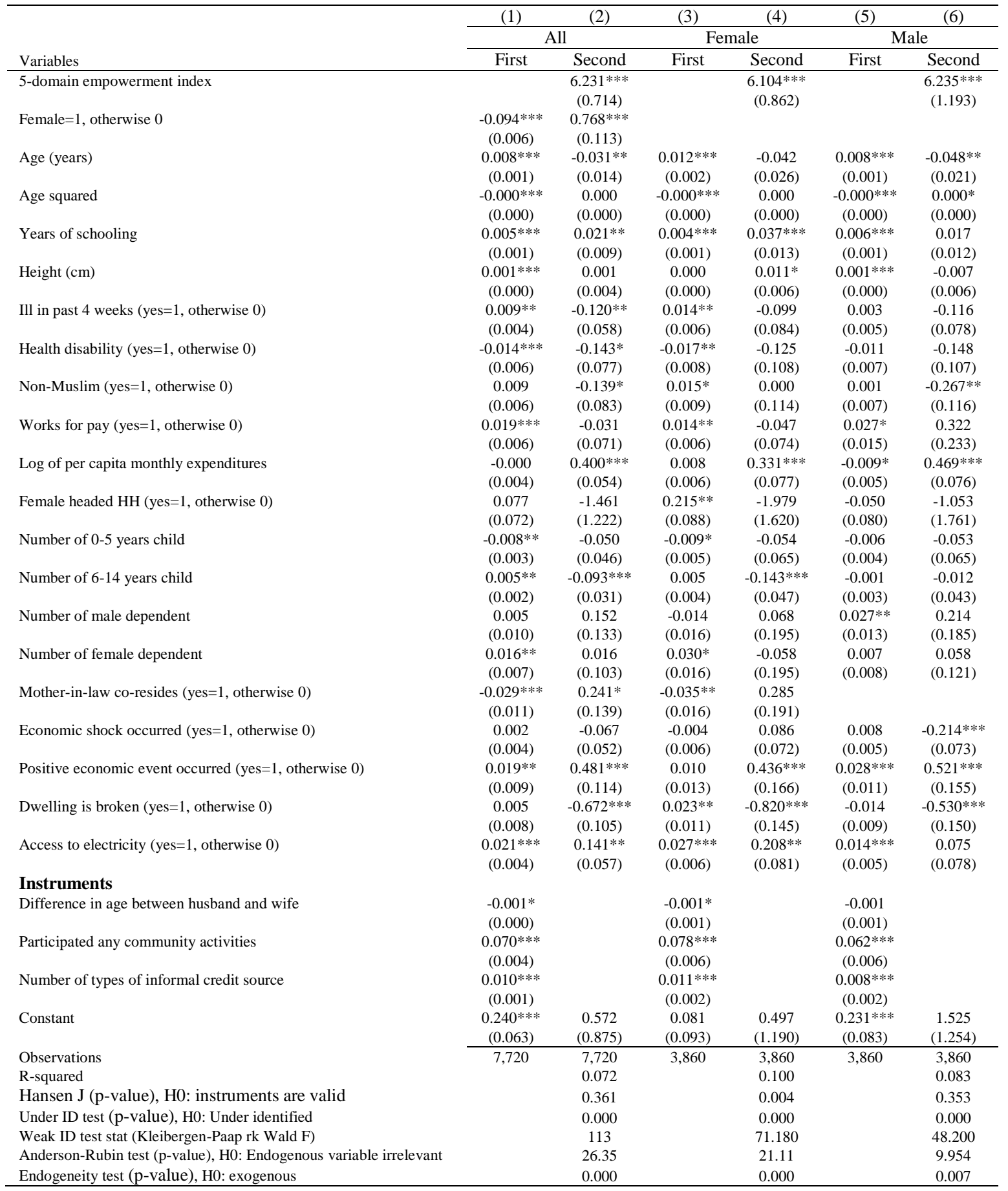

Note: (1) Robust standard errors in parentheses (2) *** $\mathrm{p}<0.01, * * \mathrm{p}<0.05, * \mathrm{p}<0.1$ (3) fixed effects estimates are based on OLS regression. (4) Community is defined at Union level. (5) Regression model also include division dummies. 